Invited review

\title{
Present-day uplift of the European Alps: Evaluating mechanisms and models of their relative contributions
}

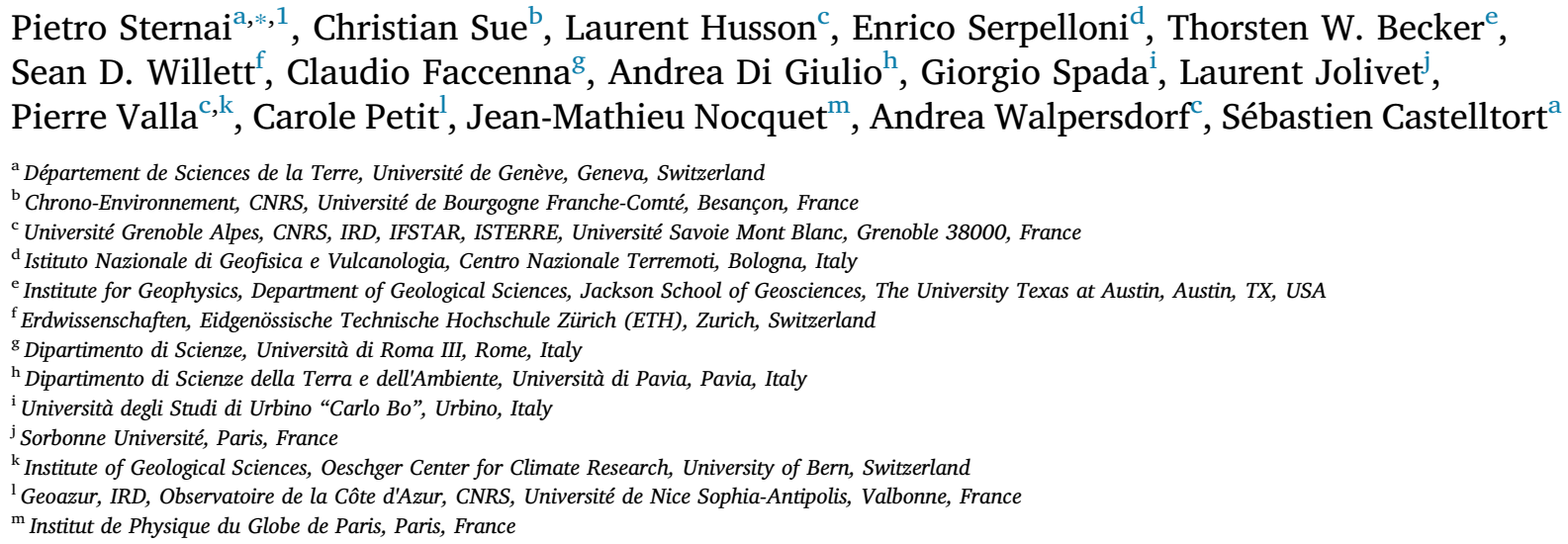

\section{A R T I C L E I N F O}

\section{Keywords:}

European Alps

Vertical displacement rate

Deglaciation

Erosion

Lithospheric structural changes

Mantle flow

\begin{abstract}
A B S T R A C T
Recent measurements of surface vertical displacements of the European Alps show a correlation between vertical velocities and topographic features, with widespread uplift at rates of up to $\sim 2-2.5 \mathrm{~mm} / \mathrm{a}$ in the North-Western and Central Alps, and $\sim 1 \mathrm{~mm} / \mathrm{a}$ across a continuous region from the Eastern to the South-Western Alps. Such a rock uplift rate pattern is at odds with the horizontal velocity field, characterized by shortening and crustal thickening in the Eastern Alps and very limited deformation in the Central and Western Alps. Proposed mechanisms of rock uplift rate include isostatic response to the last deglaciation, long-term erosion, detachment of the Western Alpine slab, as well as lithospheric and surface deflection due to mantle convection. Here, we assess previous work and present new estimates of the contributions from these mechanisms. Given the large range of model estimates, the isostatic adjustment to deglaciation and erosion are sufficient to explain the full observed rate of uplift in the Eastern Alps, which, if correct, would preclude a contribution from horizontal shortening and crustal thickening. Alternatively, uplift is a partitioned response to a range of mechanisms. In the Central and Western Alps, the lithospheric adjustment to deglaciation and erosion likely accounts for roughly half of the rock uplift rate, which points to a noticeable contribution by mantle-related processes such as detachment of the European slab and/or asthenospheric upwelling. While it is difficult to independently constrain the patterns and magnitude of mantle contributions to ongoing Alpine vertical displacements at present, future data should provide additional insights. Regardless, interacting tectonic and surface mass redistribution processes, rather than an individual forcing, best explain ongoing Alpine elevation changes.
\end{abstract}

\section{Introduction}

The elevation and relief of mountain ranges evolve accordingly to the tectonic and climatic histories (e.g. England and Molnar, 1990; Molnar and England, 1990; Raymo and Ruddiman, 1992; Avouac and
Burov, 1996; Ruddiman, 1997; Willett, 1999; Braun, 2010; Carminati and Doglioni, 2012). The rate of change of mountain elevation is sensitive to the rate of change of tectonic or climatic processes and thus potentially allows discerning between the predominant tectonic or climatic control on the orogen morphology. However, detailed constraints

\footnotetext{
* Corresponding author.

E-mail address: pietro.sternai@unige.ch (P. Sternai).

${ }^{1}$ Present address: The Department of Earth and Environmental Sciences, DISAT, University of Milano-Bicocca, Milano, Italy.
} 
on the many interdependent processes and topographic effects involved by tectonic and climatic changes are required.

In the European Alps, major Pliocene-Quaternary tectonic and climatic processes, including widespread glaciation (e.g. Penck, 1905; Preusser et al., 2010) and various mechanisms of lithospheric strain (e.g. Argand, 1916; Schmid et al., 2017), have been documented for over a century, contributing much of our knowledge about orogenic processes in general. Recent works called upon various combinations of "surface" or "deep-seated" forces related to Pliocene-Quaternary climatic or tectonic events in order to explain current measurements of elevation changes in time (e.g. Delacou et al., 2004; Sue et al., 2007; Serpelloni et al., 2013; Walpersdorf et al., 2015; Nocquet et al., 2016). However, the relative contributions of surface or deep-seated forces to the vertical displacement rate as well as the relationships between the vertical and horizontal components of motion are still elusive.

Here, we present an integrated characterization of the processes controlling the current Alpine surface vertical displacement rate. We first provide a reference map of Global Positioning System (GPS) measurements of the current Alpine vertical displacement rate (Section 2). Then, we review the surface mass redistribution-related or tectonicrelated processes that may affect the current vertical motion of the Alps and compare previously proposed and new models of their relative contributions to the observed surface vertical displacement rate. In the spirit of a review, we report proposed magnitudes of vertical displacement rate for each mechanism (Section 3). However, strong assumptions are unavoidable in modeling a complex system such as the Alps, and the uncertainty within models, rarely quantified, is likely larger than the observed vertical displacement rate. We thus caution the reader that any consideration regarding modelled magnitudes in this section should be taken as our interpretative assessment. Instead, comparisons between and considerations regarding the spatial patterns of each contribution (Section 4) should be seen as likely more robust. Our main conclusion (Section 5) is that current Alpine vertical motion is unlikely to be related to an individual process, but rather is the result of multiple contributions adding up differently along and across the Alpine strike.

\section{Measurements of ongoing Alpine vertical displacement rates}

\subsection{Overview}

Continuous Global Navigation Satellite System (GNSS) networks provide increasingly detailed information on the three-dimensional surface velocity field in the Euro-Mediterranean area. Serpelloni et al. (2013) provided a first synoptic view of vertical ground motion rates over the great Alpine region, integrating data from several GNSS networks. Levelling data have long revealed the uplift rates of the Swiss Alps with respect to the foreland (Schaer and Jeanrichard, 1974; Gubler et al., 1981). Despite a few disagreements, independent analyses of the GNSS and GNSS/levelling datasets spanning decades to a century show overall consistency in the main trends (in terms of location and magnitude) of the relative uplift rates (Nocquet et al., 2016).

Here we update the solution of Serpelloni et al. (2013) using vertical GPS data up to the end of 2016 at 555 stations (while Serpelloni et al. (2013) processed data between 1998 and 2011 at 278 stations), with an average observational time span of 7.5 years (minimum 2.5 and maximum 23 years) (Fig. 1). The position time-series have been obtained adopting a three-step procedure: 1) raw phase data reduction, 2) combination of loosely constrained network solutions and reference frame definition and 3) time-series analysis, including velocity estimates and spatial filtering of common mode errors. The raw GPS observables have been analysed using the GAMIT/GLOBK software package version 10.6 (Herring et al., 2015), adopting standards defined in the framework of the IGS "Repro2 campaign" (http://acc.igs.org/ reprocess $2 . \mathrm{html}$ ). Loosely constrained solutions have been combined with the global solution of the IGS network by the MIT, realizing a global reference frame by applying generalized constraints (Dong et al., 1998). We define the reference frame by minimizing the velocities of the IGS08 core stations (http://igscb.jpl.nasa.gov), while estimating a seven-parameter transformation with respect to the GPS realization of the ITRF2008 frame (Altamimi et al., 2011). In the third step, we analyse the position time series in order to estimate and correct offsets due to stations equipment changes, while simultaneously estimating annual and semi-annual periodic signals and a linear velocity term. For additional details on the GPS data processing and post-processing the reader is referred to Serpelloni et al. (2018). The GPS velocity field in Switzerland is augmented by using an additional GPS velocity field from the AGNES (Automated GNSS Network for Switzerland) network, made available by Swisstopo (http://pnac.swisstopo.admin.ch). Velocities from this solution have been aligned to ours using sites in common between the two databases, while estimating a 6-parameters transformation (Serpelloni et al., 2013; Serpelloni et al., 2016). Prior to this operation, the velocity uncertainties provided by the AGNES solution (representing the formal uncertainty arising from rigorous adjustment using original daily normal equations) are increased by a factor of 15 since they underestimate the true value by a similar amount (E. Brockmann, 2018, personal communication). Vertical GPS/GNSS velocities are provided in Table S1. In the Western Alps, vertical velocities are consistent with those of Nocquet et al. (2016) and Walpersdorf et al. (2015).

In Fig. 1a, we plot the data and an interpolated surface together with the horizontal velocity field modelled by Serpelloni et al. (2016). We use only GPS/GNSS data, since these alone provide homogeneous coverage over the Alps. However, Fig. S1 shows that our preferred solution has reasonably good spatial agreement with levelling data (Schlatter et al., 2005). The interpolated surface bears a degree of uncertainty and probabilistic analyses suggest more conservative magnitudes (Husson et al., 2018), but the main pattern is robust.

\subsection{Data interpretation}

Since at least the Oligocene, the Northern Apennine and Dinaride orogenic belts are characterized by continental subduction to the SW under the Apennines and to the NE under the Dinarides. In addition, the Apennine slab is rolling back to the NE. Both systems affect the Alpine structures at their terminations (e.g. Ratschbacher et al., 1991; Rosenbaum and Lister, 2004; Schmid et al., 2004; Vignaroli et al., 2008; Bennett et al., 2008; Mitterbauer et al., 2011; Šumanovac, 2015; Handy et al., 2015). Today's Alpine horizontal deformation is consistent with the kinematics imposed by these boundary conditions, with AdriaEuropean motion described by a counterclockwise rotation around an Euler pole positioned in the northwestern Po plain (e.g. Anderson and Jackson, 1987; Collombet et al., 2002; Battaglia et al., 2004; Nocquet and Calais, 2004; D'Agostino et al., 2008; Rolland et al., 2012). The resulting horizontal strain involves shortening in the Eastern Alps, dextral shear in the Central Alps, and no deformation, or very slow horizontal extensional deformation in the Western Alps (e.g. Slejko et al., 1989; Doglioni, 1990; Sue et al., 2007; Walpersdorf et al., 2015; Serpelloni et al., 2016). The geodetic vertical velocity measurements show that the Western Alps around the Vanoise-Zermatt area and Central Alps near Davos are currently uplifting at maximum local rates of $\sim 2 \mathrm{~mm} / \mathrm{a}$ and $\sim 2.5 \mathrm{~mm} / \mathrm{a}$, respectively, while values gradually decrease to zero and become negative toward the Eastern and SouthWestern Alps (Fig. 1a,b). Regions undergoing uplift rates $>1 \mathrm{~mm} / \mathrm{a}$ belong almost exclusively to the Alpine arc and are systematically located within the Last Glacial Maximum (LGM) ice extent (Ehlers and Gibbard, 2004). The analysis of the structures that accommodate the present-day surface vertical displacement rates from our preferred solution is beyond the scope of this study. However, major Alpine tectonic lineaments often wrap around, rather than cut through, domains with distinct uplift rates from our solution. For instance, the fast uplifting Central Alpine sector is bound by the Periadriatic, Giudicarie and 

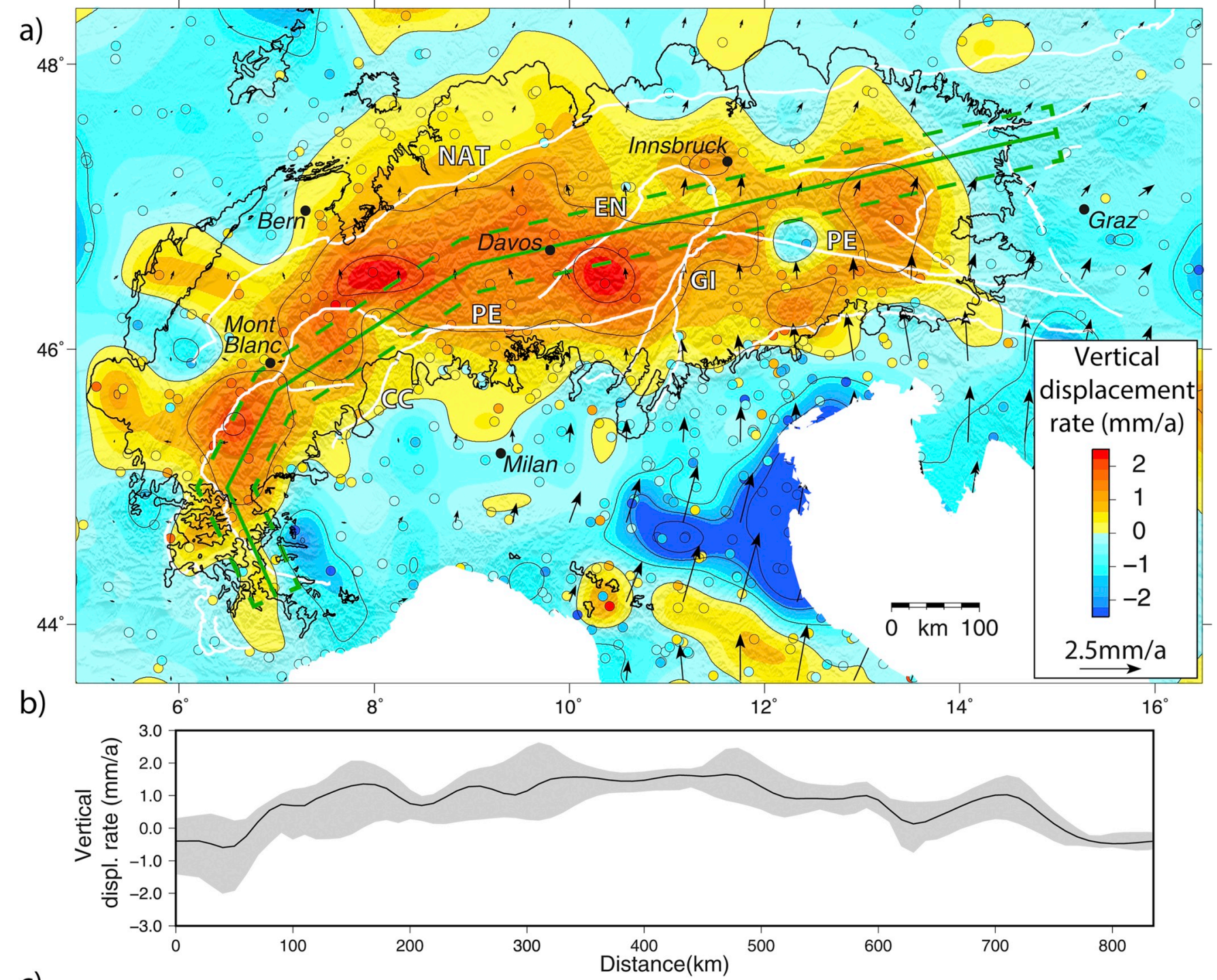

C)
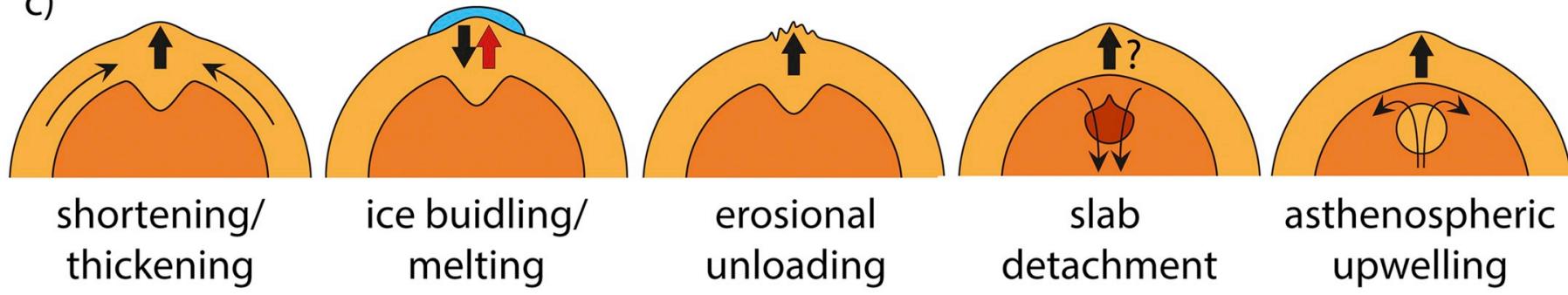

asthenospheric

Fig. 1. (a) Measurements of ongoing Alpine vertical displacement rate (see Section 2 for detail). Values at circles (locating GPS/GNNS stations) are interpolated using the GMT blockmean and surface commands at a spatial resolution of $30 \mathrm{~km}$ and with a tension factor of 0 (minimum curvature solution). Isolines at $1 \mathrm{~mm} / \mathrm{a}$ intervals are shown with thin black lines. Black arrows show the horizontal velocity field as from the model by Serpelloni et al. (2016). The thick black line shows the LGM ice extent as from (Ehlers and Gibbard, 2004). White lines show major Alpine tectonic lineaments (Schmid et al., 2004), NAT - Northern Alpine Thrust, CC - CentovalliCanavese line, PE - Periadriatic line, GI - Giudicarie line, EN - Engadine line. (b) Along-strike West-East vertical displacement rate against distance swath profile (location shown by green lines in a). The solid line shows mean values, the shaded region shows minimum and maximum values. (c) Schematic representation of the main proposed mechanisms of Alpine vertical displacements. Lighter or darker colors denote lighter or denser materials. All mechanisms are discussed in details in the main text (Section 3).

Engadine lines, while the fast uplifting Western Alpine region lies between the Centovalli-Canavese lines and the main northern Alpine thrust front. Of particular importance for this study is that present-day uplift rates are faster where horizontal shortening is limited (in the Western and Central Alps), while regions undergoing significant horizontal shortening (the Eastern Alps) are uplifting at slower rates. Such a first-order pattern is a robust feature, largely independent of the method used to interpolate the scattered data (Serpelloni et al., 2013; Serpelloni et al., 2016).

\section{Analysis of the modern Alpine vertical displacement rates}

Elevation changes are generally associated with changes in crustal thickness (e.g. Heiskanen and Vening Meinesz, 1958). However, 

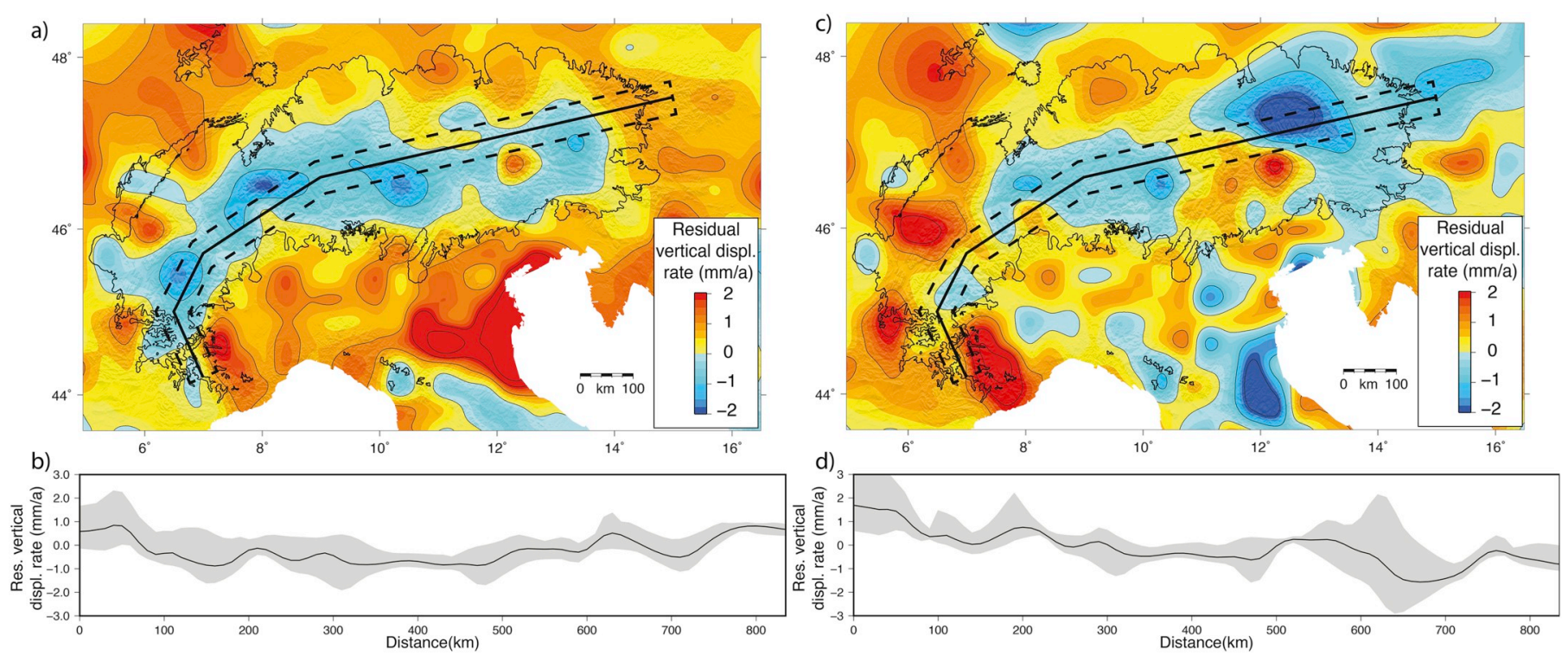

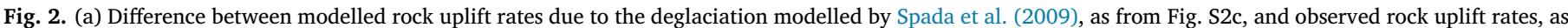

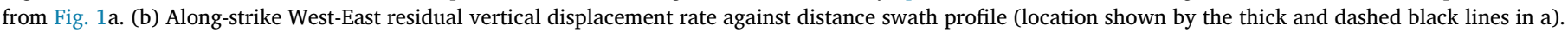

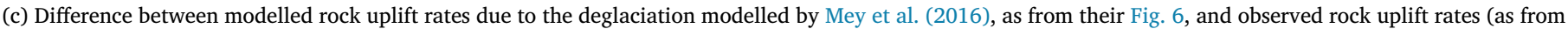

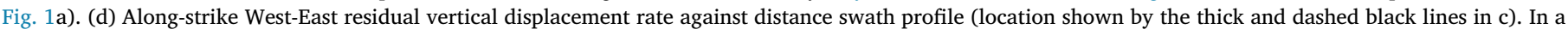

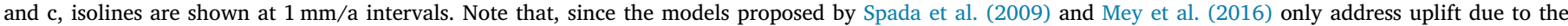

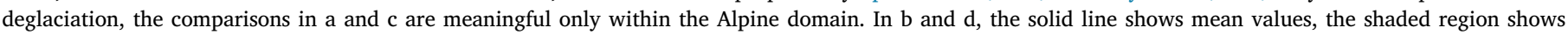
minimum and maximum values.

exceptions to this correlation exist. For instance, topographic loads with wavelengths shorter than $\sim 100-200 \mathrm{~km}$ do not necessarily cause the sinking of the crust into the mantle, but may rather produce lithospheric flexure over wide areas (e.g. Watts, 2009). In addition, the mantle flow actively modulates the surface topography through vertical tractions (e.g. Hager et al., 1985; Cazenave et al., 1989; Gurnis, 1993; Le Stunff and Ricard, 1995; Christensen, 1998; Lithgow-Bertelloni and Silver, 1998; Braun, 2010; Husson et al., 2014; Sternai et al., 2016a; Gvirtzman et al., 2016). This latter contribution to surface elevation changes is often referred to as "dynamic" to emphasize the forcing by moving mass anomalies, as opposed to the quasi-static mass anomalies (e.g. topographic loads) that control the amount of "isostatic" topography. Whether or not the term "dynamic" includes topographic effects due to processes involving the mantle lithosphere is controversial (e.g. Flament et al., 2013). Here, we only include sub-lithospheric processes in the definition and consider variations in lithospheric thickness as providing an isostatic contribution to surface elevations (Fig. 1c).

Processes that likely originate the rock uplift (sensu England and Molnar, 1990) shown in Fig. 1a and b are the isostatic adjustment to surface mass redistribution due to (1) deglaciation since the LGM and (2) erosion of the orogen, the isostatic adjustment to (3) lithospheric structural changes and (4) the dynamic traction due to sub-lithospheric mantle convection. These mechanisms and their potential contributions to the observed rock uplift rates are assessed hereafter.

\subsection{Alpine uplift by isostatic adjustment to deglaciation}

\subsubsection{Overview}

Approximating the behaviour of the Alpine lithosphere to that of a viscoelastic medium (e.g. Turcotte and Schubert, 2002; Watts, 2009), the characteristic viscoelastic relaxation time, $\tau=2 \eta / E$ (where $\eta$ and $E$ are, respectively, the mean asthenospheric viscosity and elastic modulus), defines the system response reference timescale. Reasonable estimates of $\tau$ for the Alpine system give values between a few thousands and a few tens of thousands of years (e.g. Digby, 1981; Jackson and Paterson, 1987; Forte and Mitrovica, 1996). In the Alps, geochronological and geomorphological studies define a maximum age for the onset of the LGM deglaciation of $\sim 21 \mathrm{ka}$ (e.g. Ehlers and Gibbard, 2004; Ivy-Ochs et al., 2006). Since the characteristic timescale of the deglaciation is comparable to the viscoelastic relaxation time, viscoelastic effects are expected to be important and provide a substantial contribution to the currently observed uplift rate.

\subsubsection{Modeling results and interpretation}

With a viscoelastic Earth model and assuming a simplified LGM ice mass, Gudmundsson (1994) predicted post-LGM rebound rates comparable in magnitude to modern geodetic measurements. However, he cautioned about the need for more accurate assessments as to the rheological parameters and geometrical constraints involved with these estimates. According to Norton and Hampel (2010) post-LGM unloading may result in uplift rates $>10 \mathrm{~mm} / \mathrm{a}$ during the early stages of the deglaciation (i.e. $\sim 20-15 \mathrm{ka}$ ), but such values quickly reduce to $0.3-0.4 \mathrm{~mm} / \mathrm{a}$ after $\sim 13 \mathrm{ka}$, when the viscous deformation becomes dominant with respect to the elastic strain. Slightly lower, but similar values were obtained by Stocchi et al. (2005) and Spada et al. (2009) based on the sea-level equation approach (Farrell and Clark, 1976). Spada et al. (2009), in particular, estimate up to $\sim 0.5 \mathrm{~mm} / \mathrm{a}$ of nearpresent uplift rates due to the deglaciation since the LGM and the melting of the remote ice-sheets in the far-field of the Mediterranean based on the ICE-5G model of Peltier (2004) (Fig. S2). Barletta et al. (2006) estimated some $0.4-0.5 \mathrm{~mm} / \mathrm{a}$ of local uplift rate due to the glacier reduction during the 1996-1999 time interval in the Western Alps. Overall, these models account for $\sim 10-30 \%$ of the geodetically determined rock uplift rates in the Western/Central Alps and reach up to $\sim 50 \%$ in the Eastern Alps.

Chery et al. (2016) show that an ad hoc viscosity contrast between the Alpine foreland and central sector may allow post-LGM rebound to explain nearly all of the fast Western Alpine uplift rates as obtained by Serpelloni et al. (2013). Mey et al. (2016) argue that uplift rates due to the melting of the LGM Alpine ice cap account for $\sim 90 \%$ of the orogenscale uplift rates measured through levelling techniques by Jouanne et al. (1995), Schlatter et al. (2005) and Bruyninx (2004). However, when directly compared to our geodetically determined rock uplift 
rates (Fig. 1a), their preferred model (i.e. Fig. 6 in Mey et al., 2016) shows lower residuals in the Central Alps but higher residuals in the Western and Eastern Alps with respect to the those obtained using estimates by Spada et al. (2009) (Fig. 2). Estimates by Mey et al. (2016) also predict uplift rates higher than observed in the South-Eastern, North-Western and South-Western Alps (Fig. 2b), while over-predictions with respect to observations are almost exclusively located outside the Alpine belt if estimates by Spada et al. (2009) are considered (Fig. 2a).

The proposed contribution from post-LGM rebound to the observed rock uplift rates thus ranges widely from values as low as $\sim 10-30 \%$ (e.g., Stocchi et al., 2005; Spada et al., 2009; Norton and Hampel, 2010) to $>90 \%$ rates (e.g. Chery et al., 2016; Mey et al., 2016). However, the upper end of these estimates calibrated to post-LGM rebound in the Central Alps leads to high residuals in the Western and Eastern Alps, even if one accounts for lateral variations in lithospheric rigidity (Mey et al., 2016). We thus think that more conservative estimates of uplift rates by postglacial rebound (e.g. Stocchi et al., 2005; Norton and Hampel, 2010) and overall contributions to observations between $\sim 10-30 \%$ and up to $\sim 50 \%$ in the Western/Central and Eastern Alps, respectively, are more likely. In the Western/Central Alps, one may add to these percentages an extra $10-20 \%$ due to the present-day glacier shrinkage (Barletta et al., 2006), although this effect appears to be primarily a short-wavelength spatial feature.

\subsection{Alpine uplift by isostatic adjustment to erosion and sediment redistribution}

\subsubsection{Overview}

Although debated (e.g. Willenbring and Jerolmack, 2016), longterm sedimentary and geochronological archives document an increase in the mass of sediments released from most major mountain ranges since the onset of glaciation in the late Cenozoic (e.g. Peizhen et al., 2001; Herman et al., 2013) and the Alps have been one of the best studies examples (e.g. Kuhlemann et al., 2002; Mancin et al., 2009; Fox et al., 2015). While it is not clear whether glaciers are more effective erosive agents than rivers (e.g. Koppes and Montgomery, 2009), it is established that shifting fluvial-glacial conditions involve transient landscapes associated with significant erosional changes at $10^{1}-10^{6}$ a timescales (e.g. Koppes and Montgomery, 2009; Willett, 2010; Sternai et al., 2011; Herman et al., 2011; Sternai et al., 2013; Fox et al., 2015; Sternai et al., 2016b). The density of upper crustal rocks and sediments exceeds that of ice by a factor of $\sim 3$, which implies that erosion rates in the order of the millimetre per year sustained throughout glacial-interglacial cycles produce surface load variations comparable to those due to ice building/melting (e.g. Champagnac et al., 2009; Sternai et al., 2016b).

\subsubsection{Modeling results and interpretation}

Based on sediment budget analysis and the assumption that valleys and lakes became sedimentologically closed since the deglaciation, Hinderer (2001) estimated a mean Alpine post-LGM erosion rate of $\sim 0.6 \mathrm{~mm} / \mathrm{a}$. These values are roughly consistent with spatially averaged denudation rates inferred from cosmogenic nuclide analysis yielding values between 0.2 and $0.3 \mathrm{~mm} / \mathrm{a}$ at postglacial timescales in the Alpine foreland and up to $0.9 \mathrm{~mm} / \mathrm{a}$ along the central axis of the orogen (Fig. 3a and references therein), in general agreement with the pattern reported by Wittmann et al. (2007). Valley-scale studies suggest postglacial erosion rates of the order of a few mm/a with maximum values of up to a few $\mathrm{cm} / \mathrm{a}$ and high variability within very small distances due to the transient nature of landscapes adjusting to the glacialinterglacial transition (e.g. Brocard et al., 2003; Korup and Schlunegger, 2007; Norton and Hampel, 2010; Valla et al., 2010; van den Berg et al., 2012; Saillard et al., 2014; Rolland et al., 2017; Petit et al., 2017). Despite the variability of erosion rates across spatial and temporal scales, one can recognize a first order agreement between the spatial distribution of Alpine erosion and rock uplift rates (Fig. 3b), which may reflect a link between denudation and the associated isostatic response to unloading (e.g. Schlunegger and Hinderer, 2001; Wittmann et al., 2007). Somewhat higher erosion rates are observed during the Quaternary and the deglaciation with respect to pre-Quaternary values, i.e. prior to the onset of the Northern Hemisphere glaciation (e.g. Fox et al., 2015; Grischott et al., 2017).

Assessing surface load changes and resulting uplift rate due to rock mobilization by erosion is difficult because the sediment pathway may involve storage in intramontane basins, floodplains, fans and terraces within predominantly erosional landscapes (e.g. Castelltort and Van Den Driessche, 2003; Romans et al., 2015). Boreholes and geophysical surveys allow relatively detailed reconstructions of the sedimentary fills within major Alpine valleys (e.g. Stucki and Schlunegger, 2013). Using a viscoelastic model with spatially variable plate elastic thickness averaging to $20 \mathrm{~km}$ and assuming that valley fills are entirely of postglacial origin, Mey et al. (2016) estimate a maximum uplift rate due to post-LGM erosion and sedimentary mass redistribution reaching up to $\sim 0.5 \mathrm{~mm} / \mathrm{a}$ in the Central Alps.

Elastic flexure models were also used to estimate the time-averaged unloading due to erosion throughout the Pliocene-Quaternary and associated average uplift rate neglecting the attenuation that would result from accumulation of sediments within Alpine valleys. Champagnac et al. (2007) constrained the spatial distribution of surface load changes due to Pliocene-Quaternary erosion based on the so-called Geophysical Relief (Small and Anderson, 1998) and used an elastic flexural model to estimate the induced Alpine uplift assuming a uniform plate elastic thickness of $10 \mathrm{~km}$. These estimates provide a maximum bound on the average uplift at the million years timescale reaching up to $\sim 500 \mathrm{~m}$ along the axial part of the orogen due to glacial carving of Alpine valleys. By comparing the present-day landscape to a reconstruction of the pre-glacial Alpine topography, Sternai et al. (2012) improved the determination of the spatial distribution of long term erosion and obtained a maximum of $\sim 250 \mathrm{~m}$ of erosion-induced elastic uplift assuming a uniform $20 \mathrm{~km}$ thick elastic plate, roughly consistent with results by van der Beek and Bourbon (2008). In Fig. 4, we present an improvement on these estimates that accounts grossly for sediment deposition. We constrain the volume of material eroded from the Alps by spatial integration of the eroded material as estimated by Sternai et al. (2012), providing a volume of $\sim 300,000 \mathrm{~km}^{3}$ of sediments since the mid-Quaternary (i.e. $\sim 150,000 \mathrm{~km}^{3} / \mathrm{Ma}$ ), roughly consistent with the $\sim 160,000 \mathrm{~km}^{3} / \mathrm{Ma}$ sediment discharge rate estimated by Kuhlemann et al. (2002). According to the late-Quaternary sedimentary budget provided by Kuhlemann et al. (2002), 42\%, 23\%, 21\% and 14\% of the estimated volume of eroded material is uniformly redistributed into low-slope regions (below a $5^{\circ}$ threshold) within the Rhone, Rhine, Po and Danube catchments, respectively. We then estimate the average vertical displacement due to such a mass redistribution using an elastic plate model with uniform elastic thickness of $20 \mathrm{~km}$ (Sternai et al., 2012). The onset of major Quaternary glaciation in the Alps is constrained to have occurred at $\sim 1$ Ma from stratigraphic evidence in the Po plain (Muttoni et al., 2003) and onset of Alpine valley deepening (Häuselmann et al., 2007; Valla et al., 2011). This value is used to calculate the average vertical displacement rates in Fig. 4b-d, showing that the maximum time-averaged uplift rate due to late-Quaternary erosion and sediment deposition reaches up to $\sim 0.25 \mathrm{~mm} / \mathrm{a}$. Sediment deposition, in particular, affects the overall pattern of isostatic adjustment (Fig. 4c), but it does not significantly modify the maximum value of uplift rates along the orogen axis (Fig. $4 \mathrm{~b}$ and d).

It appears that the maximum contribution to orogen-scale uplift rates (Fig. 1a) by erosion and sediment redistribution at postglacial and late-Quaternary timescales ranges between $\sim 10-20 \%$ in the Western and Central Alps and $\sim 30-40 \%$ in the Eastern Alps. 

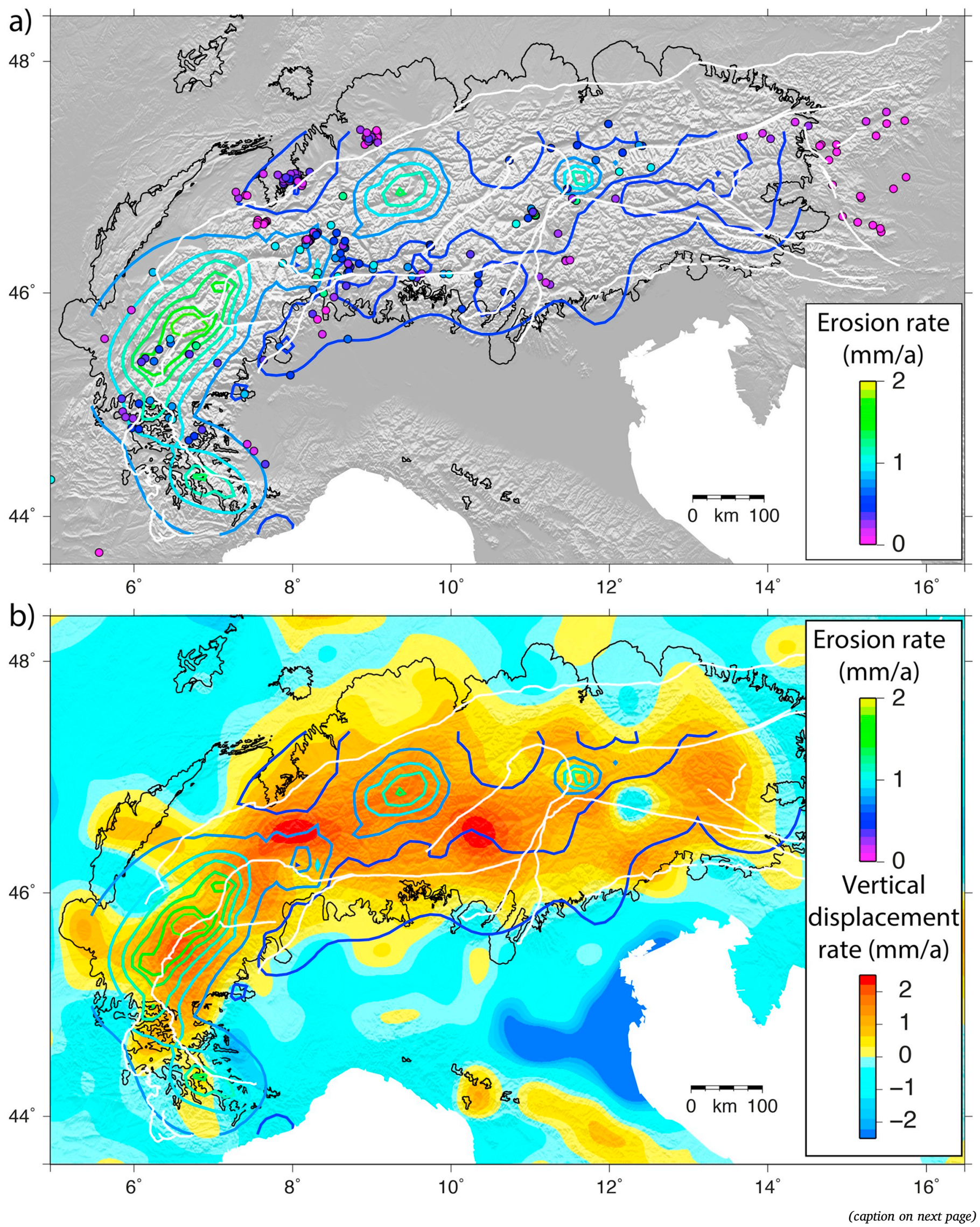


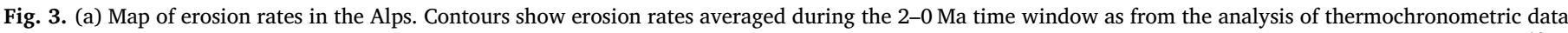

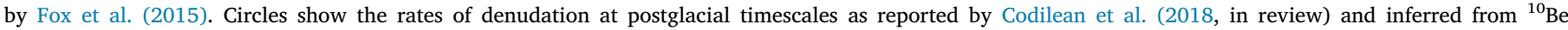

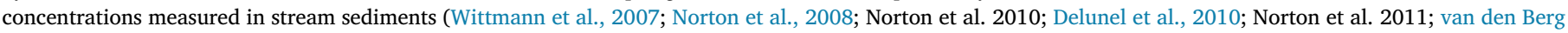

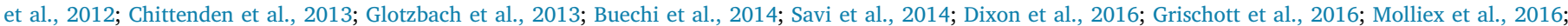

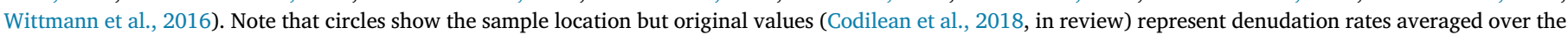

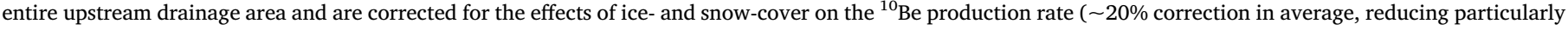

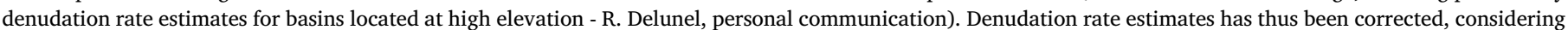

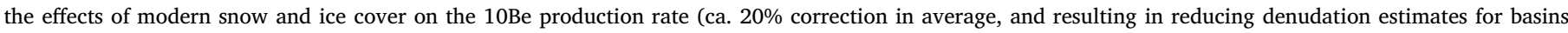

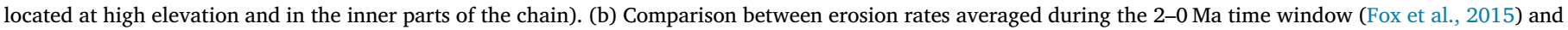
observed rock uplift rates (same as Fig. 1a).

\subsection{Alpine uplift by isostatic adjustment to lithospheric structural changes}

\subsubsection{Overview}

Information from e.g. seismic velocity and reflection data, receiver function analysis, and other geophysical and geological observations and models constrain the crustal and lithospheric structure of the Alps. The deviation from Airy type isostatic equilibrium that arises from the crustal and lithospheric Alpine structures gives insights into possible sources of rock uplift by ongoing or recent lithospheric processes. According to the recent model by Spada et al. (2013), which generally agrees with previous models (e.g. Waldhauser et al., 2002; Behm et al., 2007; Di Stefano et al., 2009; Schreiber et al., 2010; Wagner et al., 2012) the European Moho is at typical continental depths in the northern Alpine foreland $(\sim 30 \mathrm{~km})$ and dips distinctively toward the South-East in the Central Alps and toward the South in the Eastern Alps
(Fig. 5a). The Moho is deeper than $55 \mathrm{~km}$ in the Central Alps and, in the Eastern Alps, it shallows smoothly toward the east from about $50 \mathrm{~km}$ beneath the Tauern region to $\sim 30 \mathrm{~km}$ in the Vienna basin. In the Western Alps, the European Moho descends beneath the Ivrea body and the Adriatic Moho to a depth of $\sim 55 \mathrm{~km}$.

The local isostatically compensated elevation, $z_{i s o}$, depends on the thickness and density structure of the lithosphere and sub-lithospheric mantle. The surface elevation of a lithospheric column with respect to a reference elevation ( $H$, usually taken as the average mid-oceanic ridge elevation, as suggested by Lachenbruch and Morgan, 1990), is determined by the crustal thickness, $l_{c}$, and average density, $\rho_{c}$, the lithospheric mantle thickness, $l_{m}$, and average density, $\rho_{m}$, and the asthenosphere average density, $\rho_{a}$, according to the equation $z_{i s o}=\left(\left(\rho_{a}-\rho_{c}\right) / \rho_{a} l_{c}+\left(\rho_{a}-\rho_{m}\right) / \rho_{a} l_{m}\right)-H$. a)

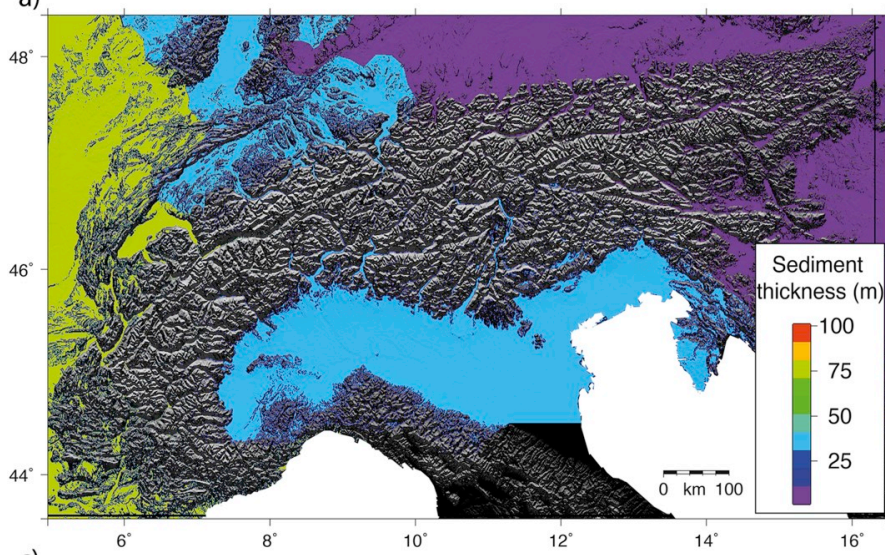

c)

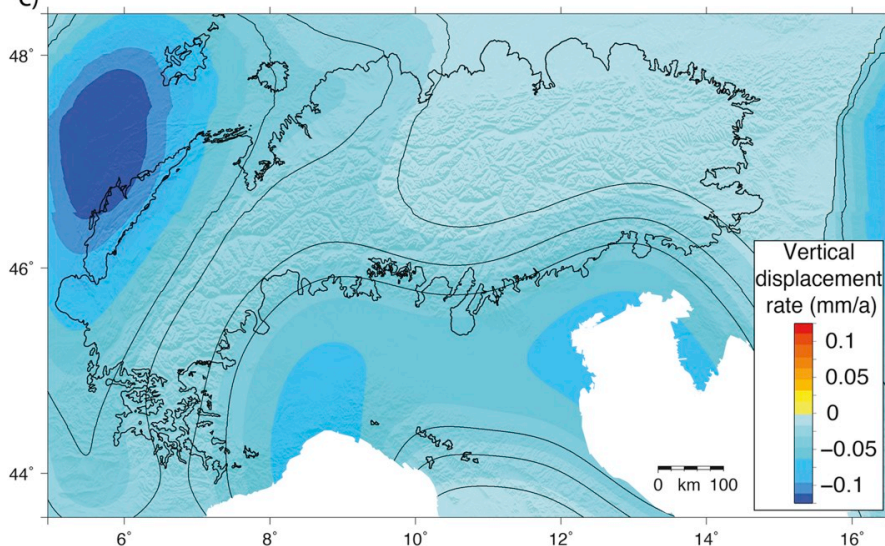

b)

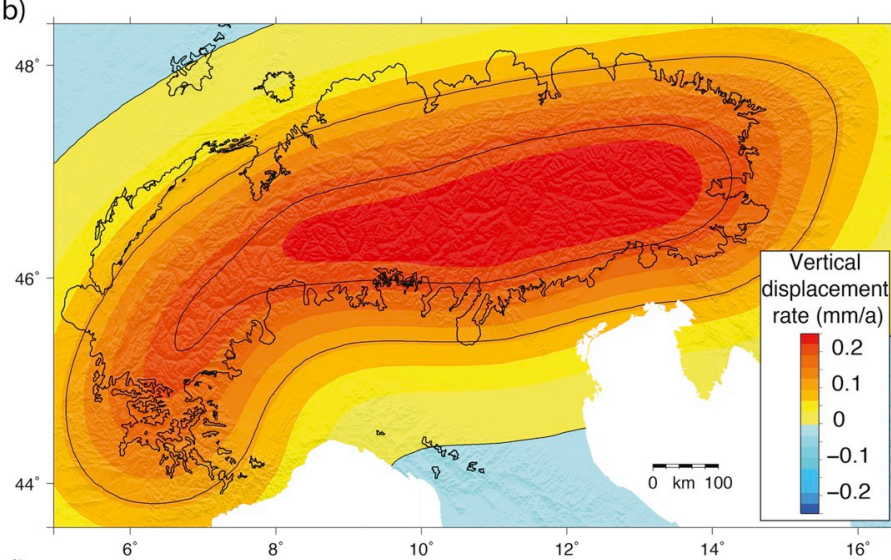

d)

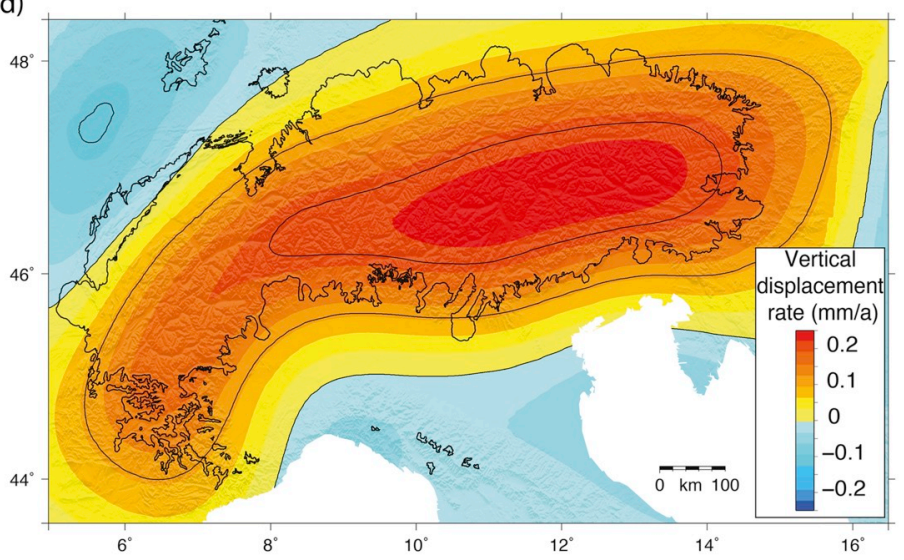

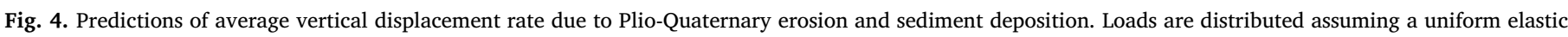

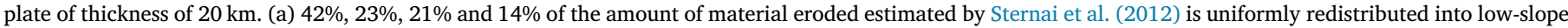

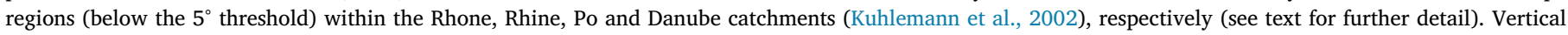

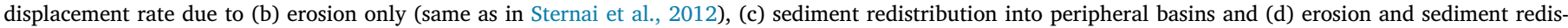

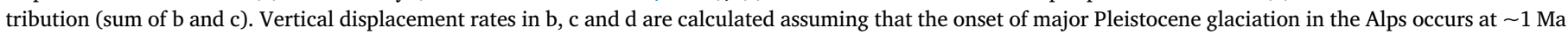

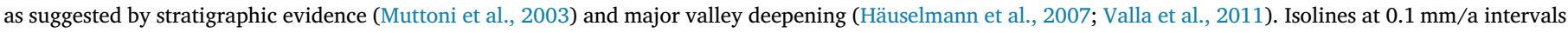
are shown in b, c and d. 

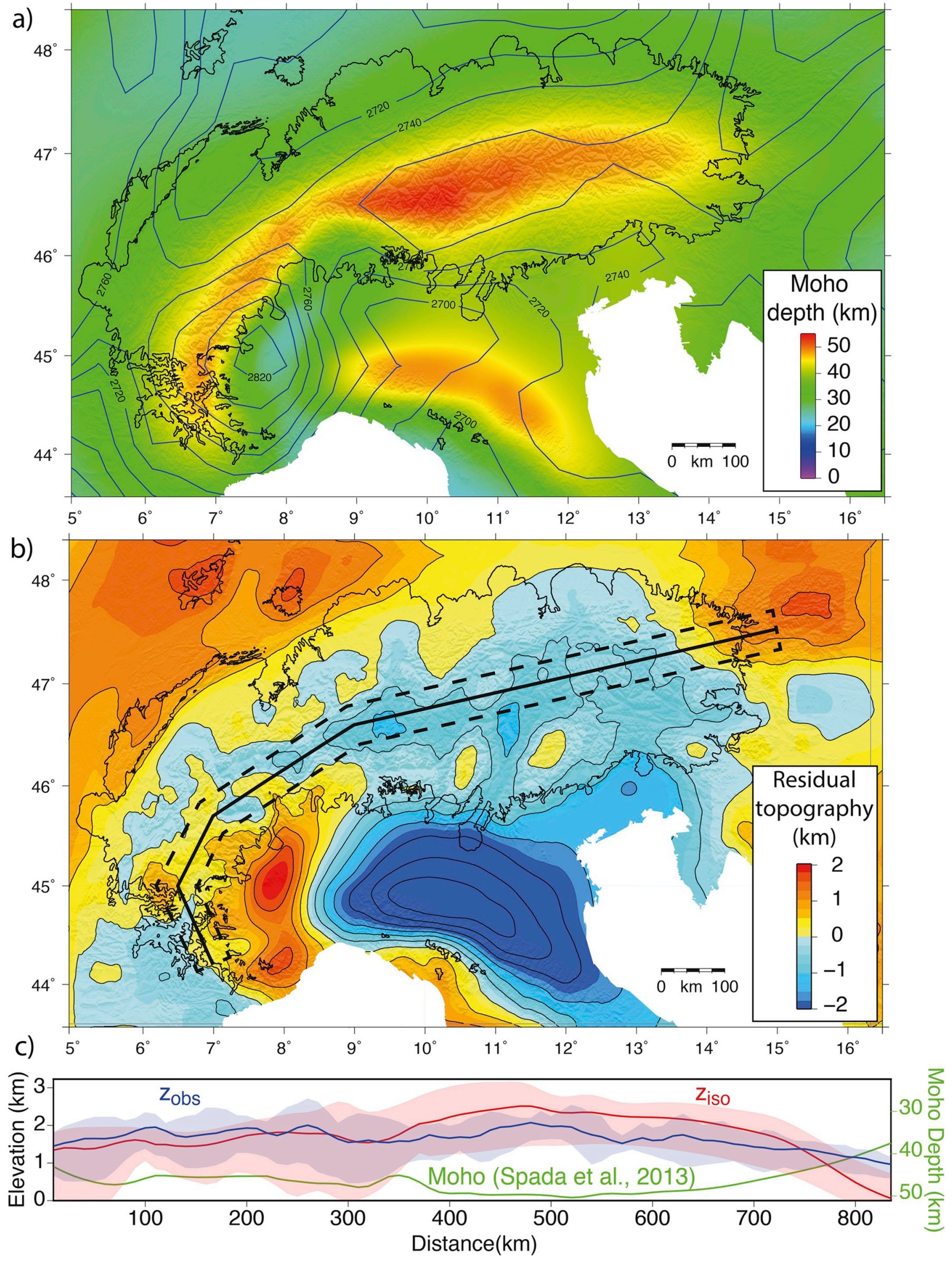


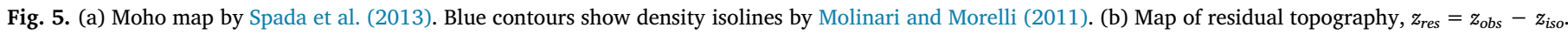

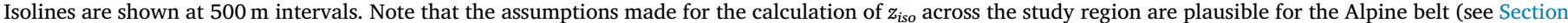

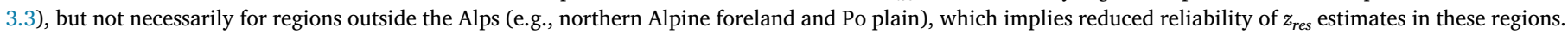

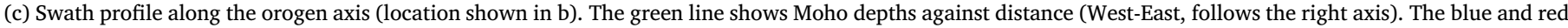

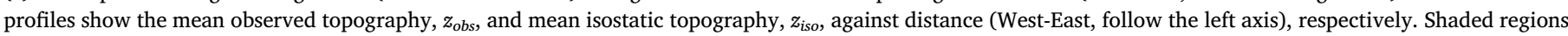
show minimum and maximum values.

\subsubsection{Modeling results and interpretation}

In Fig. 5b,c, we compare $z_{\text {iso }}$ expected from the Moho model by Spada et al. (2013) and density structure by Molinari and Morelli (2011), providing spatial variations of the terms $l_{c}$ and $\rho_{c}$, respectively, to the present-day topography. Note that several other crustal and density models covering the entire Alps exist (e.g. Tesauro et al., 2008; Di Stefano et al., 2009; Koulakov et al., 2009). Although variations arise if other crustal or density models are used, we focus here on features that appear from other available geophysical models (Fig. S3). In the calculation of $z_{i s o}$, we assume a $100 \mathrm{~km}$ thick lithosphere (but see a discussion about lithospheric structures below) and chose $\rho_{a}$ in order to minimize the regional misfit between $z_{i s o}$ and the present-day topography, $z_{\text {obs }}$. The resulting residual topography, i.e. $z_{\text {res }}=z_{\text {obs }}-z_{\text {iso }}$, is slightly positive in the Western Alps, with maximum amplitude of $\sim 250 \mathrm{~m}$ in the South-Western Italian Alps, and negative in the Central and Eastern Alps, with maximum amplitude of $\sim-750 \mathrm{~m}$ along the central axis of the belt (Fig. 5b,c). This suggests that, given the inferred lithospheric structures and densities, the Central and Eastern Alps should stand considerably higher than observed if isostasy held entirely, whereas the Western Alps should stand a few hundreds of meter below their actual elevation. Alternatively, one can assume Airy isostatic equilibrium and use the equation defining $z_{i s o}$ to calculate the spatial variations in lithospheric mantle thickness, $l_{m}$, required to achieve zero residual topography (e.g. see discussion in Gvirtzman et al., 2016). In this case, the estimated lithosphere-asthenosphere boundary would be deeper $(\sim 130 \mathrm{~km})$ beneath the Central and Eastern Alps and shallower $(\sim 90 \mathrm{~km})$ beneath the Western Alps. These values are consistent with the available geophysical constraints on the lithosphere-asthenosphere boundary (e.g. Kissling, 1993; Tesauro et al., 2013).

It is worth noting that the above estimates provide information only on the static balance due to the lithospheric structure of the Alps. The occurrence of a recent (posterior to $\sim 5 \mathrm{Ma}$ ) slab breakoff event below the Western Alps was proposed based on seismic tomography models (e.g. Lippitsch et al., 2003; Spakman and Wortel, 2004; Kissling et al., 2006; Beller et al., 2017; Kästle et al., 2018). The removal of buried load by Pliocene-Quaternary detachment of the mantle lithosphere was also independently advocated in order to explain anomalous features appearing from paleo-topographic reconstructions of the Alps (Sternai et al., 2012) and analyses of the thermochronometric Alpine record (Baran et al., 2014; Fox et al., 2015), as well as seismically active extension in the core of the Western Alps (Sue et al., 1999). The down-dip slab continuity beneath the Western and the Central Alps is, however, still debated for a continuous and apparently steeper slab may be imaged beneath the Western Alps depending on the geophysical data and tomographic inversion strategies (e.g. Piromallo and Morelli, 1997; Piromallo and Faccenna, 2004; Zhao et al., 2016).

How would late-Cenozoic slab breakoff in the Western Alps affect the ongoing pattern of Alpine uplift? Thermomechanical numerical models show that a slab breakoff occurring at depth between 100 and $140 \mathrm{~km}$, likely takes place through initial necking followed by actual tearing and detachment of the mantle lithosphere and may take up to a few millions of years (e.g. Duretz and Gerya, 2013; Duretz et al., 2014). During this time, regions as wide as $\sim 150-200 \mathrm{~km}$ are subject to uplift at rates that may reach up to $\sim 6-10 \mathrm{~mm} / \mathrm{a}$, although such high rates of uplift are generally sustained for periods shorter than $\sim 1 \mathrm{Ma}$. In these numerical models, however, one cannot separate the isostatic effect due to lithospheric unloading by detachment of the denser slab and the dynamic effect due to the viscous downward traction associated with slab sinking (see the following section). Despite the profound impact of slab detachment on topographic changes suggested by numerical models, evaluating the contribution to topographic changes by slab dynamics across natural orogens such as the Alps is difficult, also because the crust deforms actively under collisional stresses. It might be that a portion of up to $\sim 50 \%$ of the observed uplift rates is related to Pliocene-Quaternary detachment of the western European slab. However, while such contribution may apply to a region in the Western Alps that extends laterally some $150-200 \mathrm{~km}$ from the position of the proposed slab tear, i.e. in the northwestern Alpine arc, the vertical surface displacements rates in the Central and Eastern Alps are unlikely to be related to this mechanism. Even if the current impact of the detachment of the subducting European slab on the vertical surface displacement rates was of second order with respect to isostatic adjustments to deglaciation or erosion, it may account for significant lateral differences in the observed rock uplift rate between the South-Western, Central or Eastern Alpine sectors.

\subsection{Alpine uplift by dynamic adjustment due to sub-lithospheric mantle flow}

\subsubsection{Overview}

A contribution to the observed uplift rates arises from the sub-lithospheric convection, which may induce surface displacements due to vertical traction at the base of the lithosphere or crust. This contribution can be defined as the rate of change of dynamic topography $\left(z_{d y n}\right.$, sensu Hager et al., 1985), that is $\dot{z}_{d y n}$. To quantitatively assess this potential contribution, we follow the methodology described in Becker and Faccenna (2011) and Becker et al. (2015) and infer the instantaneous mantle flow of an incompressible, Newtonian fluid spherical layer with radial viscosity variations between the base of the lithosphere (imposed at $\sim 100 \mathrm{~km}$ depth) and a depth of $1200 \mathrm{~km}$. The density model was constructed by scaling the seismic velocity structure (see below) into temperature (Hager et al., 1985; Panasyuk and Hager, 2000; Steinberger and Calderwood, 2006; Simmons et al., 2010; Becker and Faccenna, 2011). $z_{d y n}$ is estimated for three discrete time-steps from the inferred radial traction due to the mantle flow assuming a free-slip surface boundary, while $\dot{z}_{d y n}$ provides an estimate of the potential dynamic contribution from the sub-lithospheric mantle flow to the observed uplift rate pattern.

\subsubsection{Modeling results and interpretation}

In Fig. 6, we show results using the recent, high resolution, P-wave Alpine seismic tomography model by Zhao et al. (2016), and the highresolution tomography model by Lippitsch et al. (2003), embedded into the global P-wave mantle tomography model by Li et al. (2008). Consistently with the inferred mantle viscosity profile from postglacial rebound studies (e.g. Cianetti et al., 2002, and references therein) and analyses of the Alpine postglacial rebound (Stocchi et al., 2005; Spada et al., 2009), the reference viscosities of the lithosphere $(0-100 \mathrm{~km})$, asthenosphere (100-300 km), upper mantle (300-670 km) and lower mantle $(670-1200 \mathrm{~km})$ are set to $50,0.5,1$, and 50 in units of $10^{21} \mathrm{~Pa} \mathrm{~s}$, respectively. Results with the model by Zhao et al. (2016) (Fig. 6a-d) show that the dynamic uplift rates are generally positive across the entire Alpine belt and attain values as high as $\sim 2 \mathrm{~mm} / \mathrm{a}$ in a region that encompasses the Southern-Central Alps, and the Po plain. This suggests a significant contribution to the vertical displacement rate from 
a)

b)

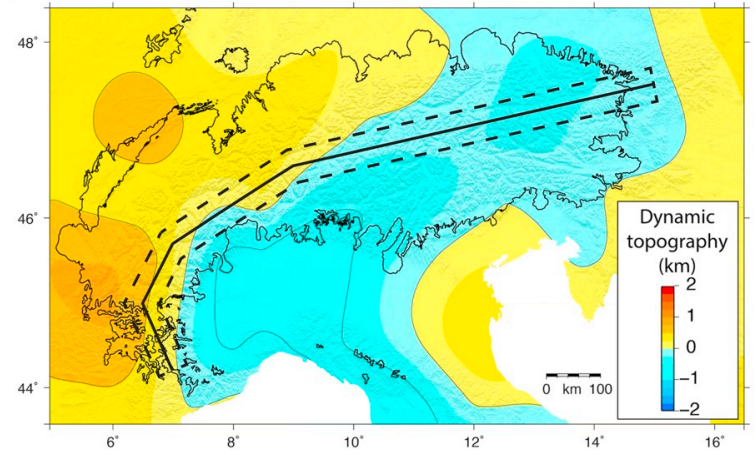

c)
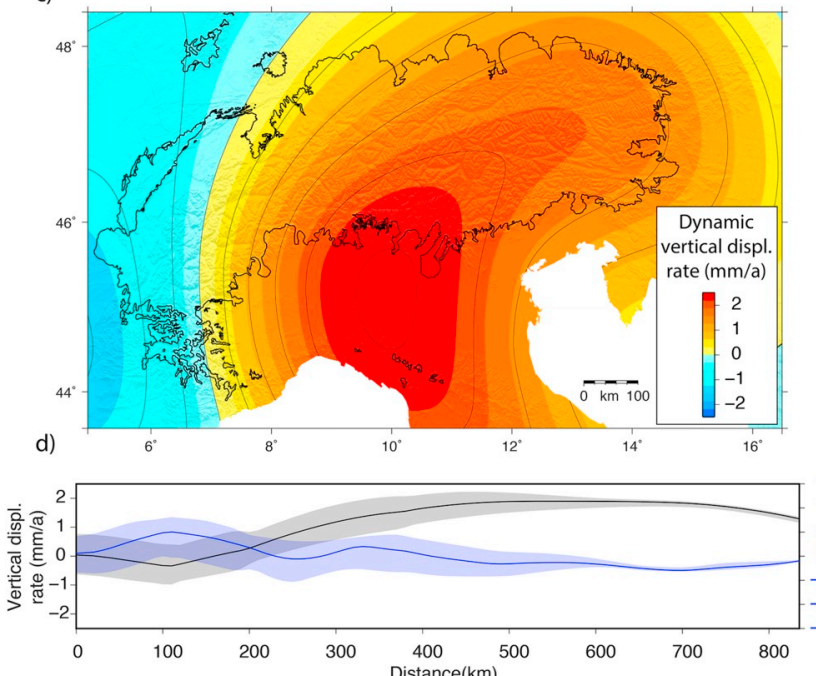

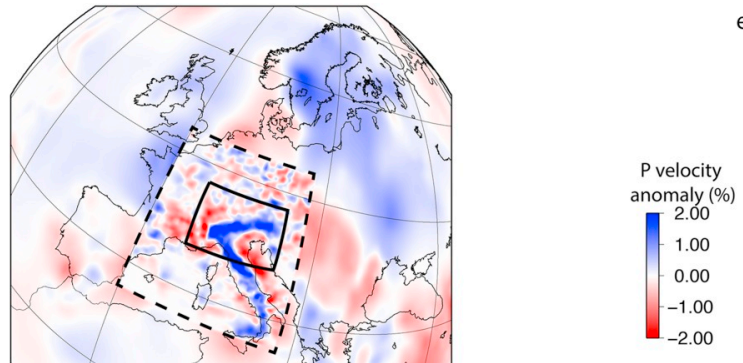

e)
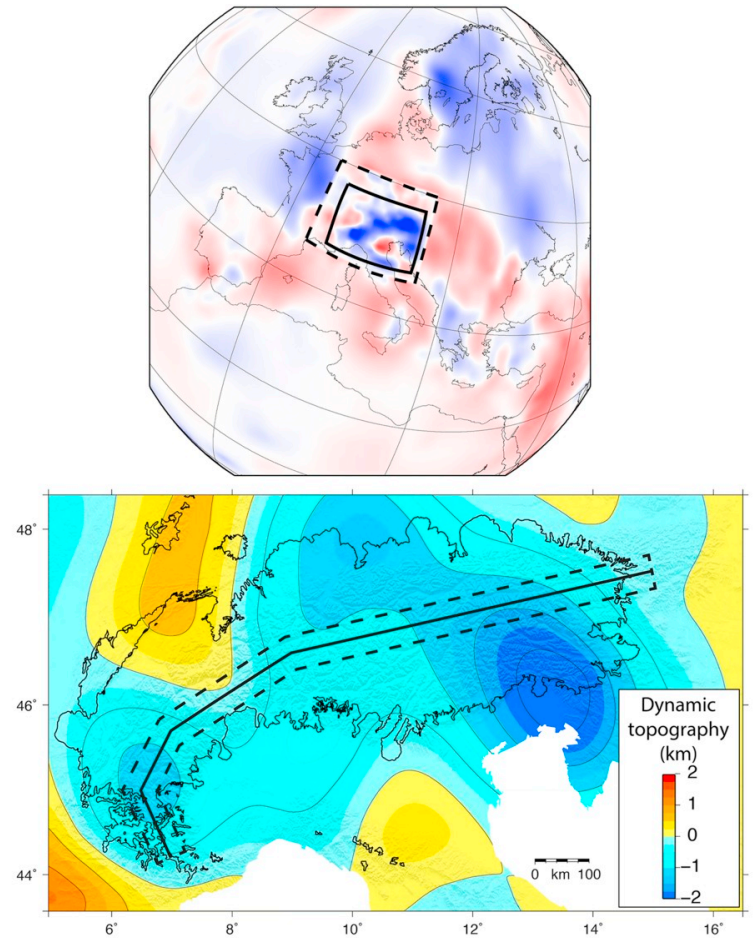

g)
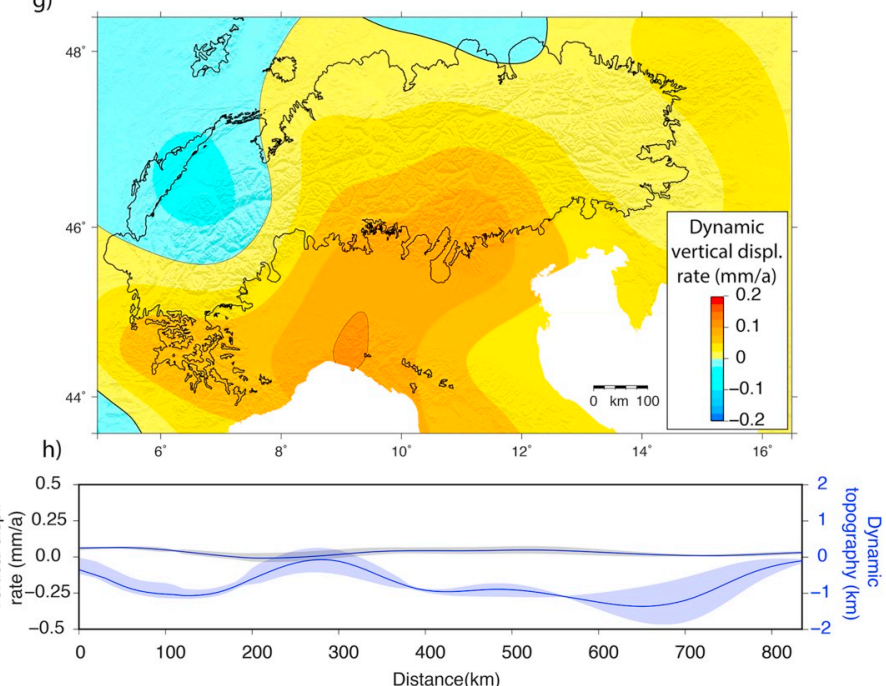

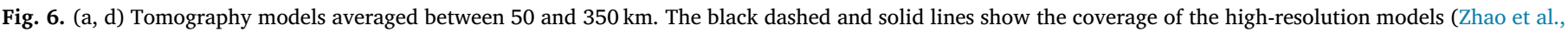

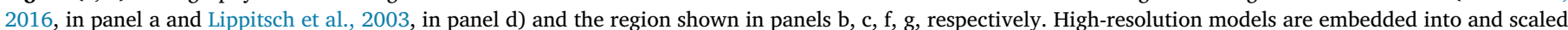

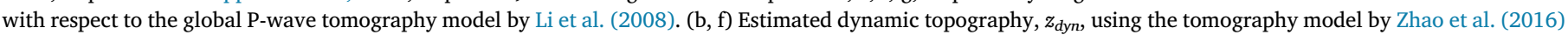

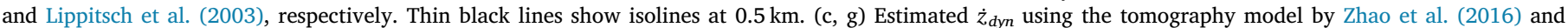

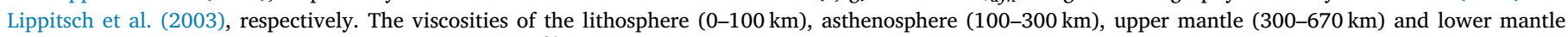

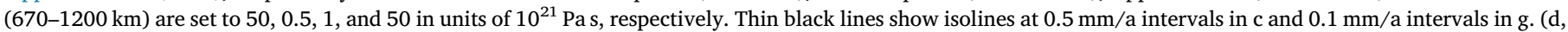

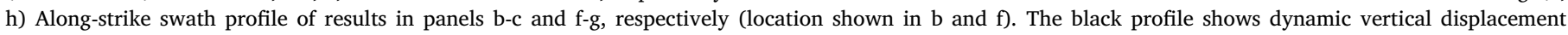

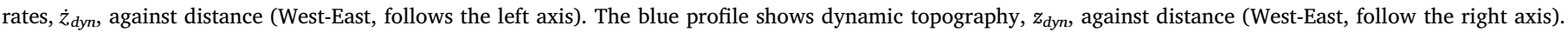
Shaded regions show minimum and maximum values.

upwelling of a low velocity zone north of the subducting European slab or increased resistance at the $410 \mathrm{~km}$ transition zone reducing the slab pull in time (Zhao et al., 2016). Results based on the model by Lippitsch et al. (2003) (Fig. 6e-h), suggesting less pronounced low velocity anomalies north of the subducting European slab and detachment of the European slab below the Western Alps, also show overall positive dynamic uplift rates across the belt, with maximum values of $\sim 0.1 \mathrm{~mm} / \mathrm{a}$ in a region encompassing the Ligurian Alps, Northern Apennines and southern Po plain. Results also show that the North-Western Alps are subject to slightly negative, if any, dynamic uplift rate, likely due to less relevant negative P-wave velocity anomalies with respect to the model by Zhao et al. (2016), and the viscous down-welling asthenospheric flow involved by the detachment and untied sinking of the European slab below this region. Both models produce uplift in the Po plain and east of longitude $14^{\circ}$, which is at odds with observations (Fig. 1a).

Assessing the contribution to the observed surface elevation changes in time by $\dot{z}_{d y n}$ is difficult because estimated magnitudes vary significantly depending on the reference density structure (Fig. 6c,g) and the imposed viscosity contrast between the lithosphere and asthenosphere (Fig. 7). For a given density structure and lithosphere-to- 

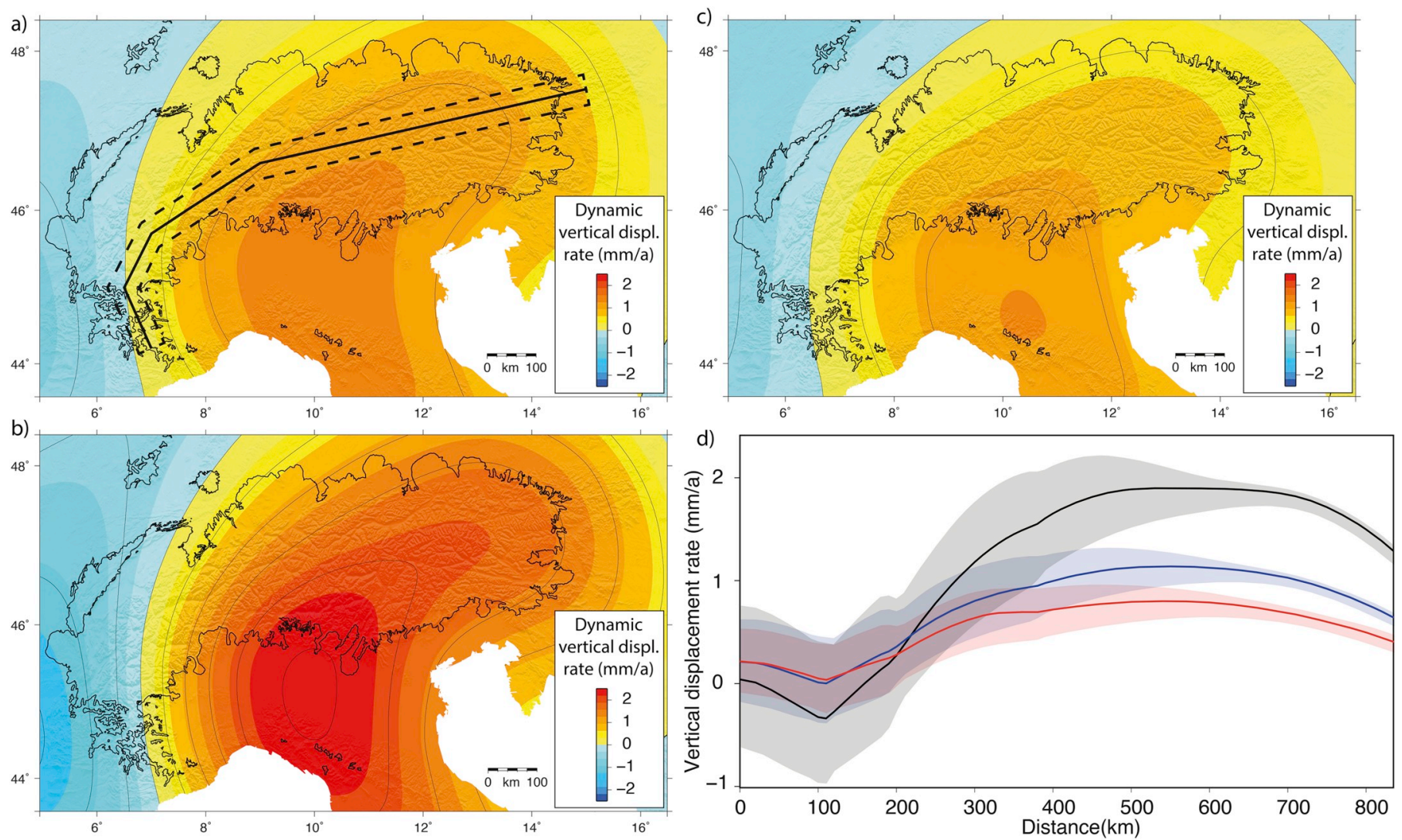

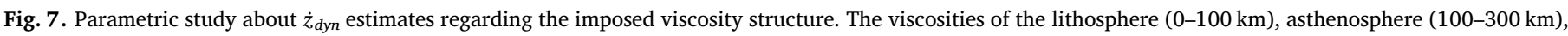

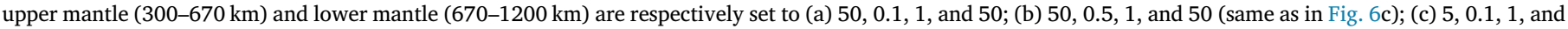

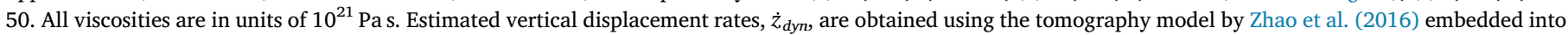

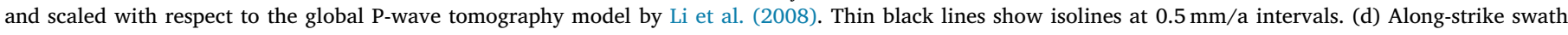

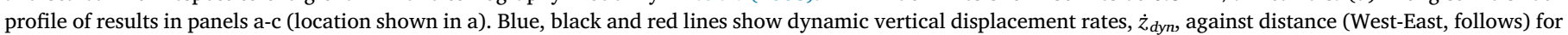
panels a, b and c, respectively. Shaded regions show minimum and maximum values.

asthenosphere viscosity contrast, in addition, the estimated magnitudes of $\dot{z}_{d y n}$ are inversely correlated to the absolute imposed asthenospheric viscosity (Fig. S4). The first order pattern of observations, involving higher rock uplift rates in the Central Alps with respect to those in the Western and Eastern Alps, is reasonably well reproduced by models of the dynamic rock uplift rates based on the most recent Alpine-scale tomographic data by Zhao et al. (2016) (Fig. 6c,d). This suggests that a considerable contribution to the Alpine-scale observed uplift rates arises from mantle convection. On the other hand, one cannot neglect that other processes are likely to contribute significantly to the observed Alpine rock uplift rates (see previous sections). In the Central Alps, the contributions to the rock uplift rate due to post-LGM deglaciation, current ice melting and erosion add up to $\sim 70 \%$ if one refers to estimates provided by Spada et al. (2009), Barletta et al. (2006) and Sternai et al. (2012). Therefore, a reasonable contribution from mantle convection to the observed uplift rate may be of $\sim 30 \%$. Without knowledge regarding the effects of slab detachment or crustal shortening/thickening on rock uplift rates (e.g. see Section 3.3) robust assessments regarding the mantle contribution to the uplift rate in the Western and Eastern Alps are precluded.

\section{Discussion}

The European Alps show an intriguing pattern of surface deformation characterized by significant horizontal shortening and relatively slow uplift rates in the East and negligible horizontal shortening and fast uplift rates in the central and western regions. This observation is difficult to reconcile with surface uplift by thickening of the buoyant crustal layer due to horizontal shortening, which is expected to provide the most relevant tectonic contribution to the topographic growth of collisional mountain ranges. Plausible estimates of the isostatic adjustment to deglaciation and erosion are sufficient to cover most of the budget of observed uplift rates in the Eastern Alps (Fig. 8). One may thus conclude that rock uplift rates in the Eastern Alps are predominantly originated by surface mass redistribution. This interpretation, however, does not allow for a tectonic contribution to vertical displacements rates resulting from crustal shortening/thickening or due to asthenospheric upwelling in the Pannonian basin (e.g. Falus et al., 2000; Cloetingh et al., 2006). Alternatively, uplift rates could be counterbalanced by other mechanisms producing subsidence. One of these mechanisms could be Eastern Alpine slab pull. However, the Dinaric slab is imaged at depths of at least $\sim 410 \mathrm{~km}$ (e.g. Zhao et al., 2016), and increased resistance at the upper-lower mantle transition should reduce the slab pull and, thus, the surface subsidence rates. Another possibility is that the lower crustal material advected into the Eastern Alps by horizontal convergence flows laterally instead of being accreted vertically. The shortening rate in the Eastern Alps is of $\sim 2 \mathrm{~mm} / \mathrm{a}$ on a $\sim 400 \mathrm{~km}$ wide portion of the range with an $\sim 45 \mathrm{~km}$ thick crust. This results in a net crustal input of $\sim 0.036 \mathrm{~km}^{3} / \mathrm{a}$ with maximum uplift rates of $\sim 0.5 \mathrm{~mm} / \mathrm{a}$ over a $\sim 65,000 \mathrm{~km}^{2}$ region encompassing the Western and Central Alps if the lower crustal flow was entirely directed toward these sectors. The horizontal upper crustal velocity field in the Eastern Alps, however, shows vectors that gradually reorient toward the east, not toward the west (Fig. 1a) and opposite upper and lower crustal flow is unlikely (e.g. Ratschbacher et al., 1991; Doglioni, 1992). Thus, while lateral flow of lower crustal material 

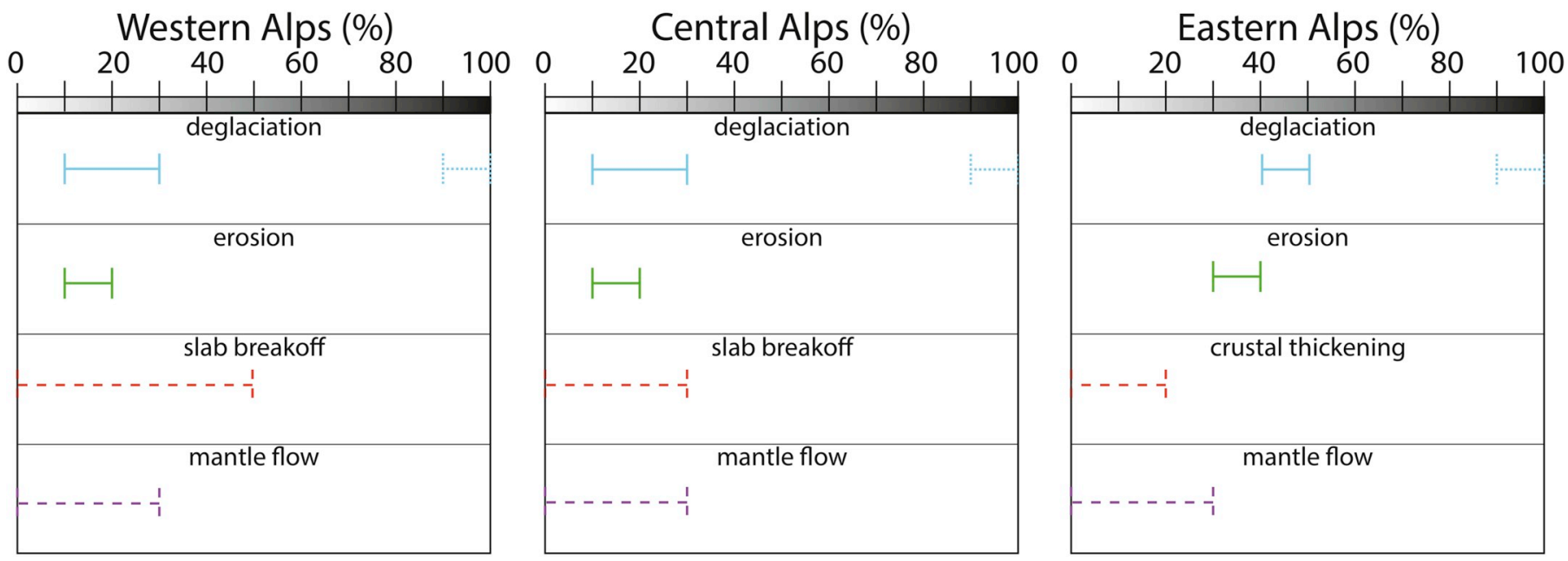

Fig. 8. Interpretative summary of proposed contributions to the observed Alpine rock uplift rates due to the deglaciation (light blue), erosion (green), lithospheric structural changes (red) and mantle convection (purple). Dashed lines highlight more speculative proposals. Dotted lines highlight proposals that we consider unlikely. See Section 3 for further detail and appropriate references.

might to some extent reduce rock uplift rates due to horizontal convergence and crustal thickening in the Eastern Alps, this mechanism can not provide additional contributions to the Western and Central Alpine rock uplift rates. Another implication of the interpretation that Eastern Alpine rock uplift rates are entirely controlled by surface mass redistribution is that, if we were to measure the eastern or Central Alpine uplift rates some $10 \mathrm{ka}$ ago, we would observe values as high as $10-15 \mathrm{~mm} / \mathrm{yr}$ since current measurements are only the viscous tail of a viscoelastic response to the bulk of the deglaciation (e.g. Spada et al., 2009; Norton and Hampel, 2010), possibly modulated by erosion rate changes on postglacial timescales (e.g. Wittmann et al., 2007; Norton et al., 2010; Norton et al., 2011; Hinderer et al., 2013).

If one assumes a uniform lithospheric and sub-lithospheric mantle structure and no other sources of uplift than the isostatic adjustment to deglaciation and erosion, similar uplift rates should be observed along the strike of the belt. Roughly double uplift rates in the Western/Central Alps than in the Eastern Alps, however, would require variations of ice melting and erosion rates of a similar magnitude. Although along-strike variations in erosion rate exist (e.g., Hinderer et al., 2013; Wittmann et al., 2007; Norton et al., 2010; Norton et al., 2011; Fox et al., 2015), the average LGM ice-cap thickness and width are increased in the Eastern Alps with respect to the Western and Central Alps (Ehlers and Gibbard, 2004), which is opposite to the observed trends in rock uplift rates. This suggests that either the Alpine lithospheric heterogeneities substantially modulate the rock uplift rate signal primarily imposed by the surface mass redistribution, or sources of rock uplift rate related to the solid Earth contribute, or both (e.g. Wölfler et al., 2008; Campani et al., 2010; Glotzbach et al., 2011; Sanchez et al., 2011; Boutoux et al., 2016). Even estimates of modern uplift rates due to the deglaciation that account for sediment redistribution as well as lithospheric heterogeneities (Mey et al., 2016), however, show significant misfit with observations (Fig. 2b), especially in the Western and Eastern Alpine sectors. Thus, the interpretation that elevation changes are mainly of surface unloading origins does not hold and contributions from the solid Earth should be accounted for.

A Pliocene-Pleistocene slab detachment event below the Western Alps (e.g. Lippitsch et al., 2003) may induce the lithosphere and surface to rebound upward and potentially allow estimates of uplift rates to approach the budget of observations. The spatial correlation between geodetic uplift rates and long-term erosion rates (e.g., Fig. 3b, Fox et al., 2015; Nocquet et al., 2016) or landscape modifications (Sternai et al., 2012) in the Western Alps may be representative of the surface response to such a deep-seated processes. However, the seismic evidence of the Western Alpine slab breakoff is uncertain (e.g. Zhao et al., 2016). In addition, even if recent slab breakoff occurred in the Western Alps, it is not clear whether the expected modifications as to the rock uplift rate may extend laterally to the Central Alps, currently subject to the highest rates of uplift. A fully convincing interpretation of the ongoing Alpine strain pattern involving predominant isostatic forces, if possible, requires additional data and investigations regarding the surface vs. deep Earth process coupling.

The viscous asthenospheric flow in response to a post- $5 \mathrm{Ma}$ detachment of the western European slab as suggested by e.g. Lippitsch et al. (2003) might imply subsidence at relatively slow rates in the North-Western Alps (Fig. 6f), which would hamper the observed rock uplift rates at the surface. However, the regional correlation between fast uplift rates in the Western Alps and a $200 \mathrm{~km}$ deep, slow velocity anomaly imaged by the tomography by Zhao et al. (2016) points toward a possible contribution by asthenospheric upwelling to ongoing surface displacements through vertical tractions (Fig. 6c). The spatial misfit between the estimated and observed peak uplift rates located $>100 \mathrm{~km}$ away from each other is likely related to the lithospheric filtering of the mantle uplift signal or to other sources of vertical displacements. For instance, the geometry of crustal structures accommodating the strain modulates the possible contribution from the sublithospheric flow to the surface displacement rates at the local scale. Inferred mantle-driven upward vertical displacement rates in the Eastern Alps are consistent with mantle upwelling in the Pannonian basin (e.g. Falus et al., 2000; Cloetingh et al., 2006). However, the easternmost Alpine surface displacement rates appear to have a component of subsidence, which might be due to sediment loading in the Pannonian basin (e.g. Royden et al., 1983). Similarly, subsidence due to sediment loading or compaction (Carminati and Martinelli, 2002) and/ or the northern Apennine slab pull (Faccenna et al., 2014) appear to override the inferred uplift rates due to mantle convection in the Po plain. As for the other mechanisms, the absolute magnitude of the possible contribution from mantle convection to the observed rock uplift rate is difficult to constrain based on current knowledge (Figs. 6, 7 and Fig. S4). However, the general first order agreement between the observed orogen-scale pattern of surface displacement rate and estimates of rock uplift rate due to the sub-lithospheric flow based on the most recent tomography by Zhao et al., 2016, point to a possibly significant contribution and we argue for $\sim 10-30 \%$ at the orogen scale.

Alpine uplift is mechanically associated with predominant extensional tectonics as tested by numerical modeling (e.g. Delacou et al., 2005; Vernant et al., 2013). Prevailing extensional faulting and minor strike-slip deformation characterize the Plio-Quaternary Western Alpine strain (e.g. Bistacchi and Massironi, 2000; Sue and Tricart, 2003; 
Champagnac et al., 2006; Tricart et al., 2006; Bauve et al., 2014; Schwartz et al., 2017) and the present-day seismicity (e.g. Maurer et al., 1997; Eva and Solarino, 1998; Sue et al., 1999; Delacou et al., 2004; Sue et al., 2007). However, although the most seismically active region between the Pelvoux, Argentera and Viso massifs (Briançonnais and Piedmont) is found where the maximum extensional deformation occurs (e.g. Maurer et al., 1997; Eva and Solarino, 1998; Sue et al., 1999; Delacou et al., 2004; Sue et al., 2007), the fastest uplift rates is in the vicinity of the Mont Blanc and Vanoise-Valais massifs (Fig. 1a) and is located by some $150 \mathrm{~km}$ to the north with respect to the Briançonnais and Piemontais areas (e.g. Vigny et al., 2002; Sue et al., 2002; Sue et al., 2007b; Walpersdorf et al., 2015). Alpine seismic catalogues only reports on a few decades of activity, but this discrepancy may suggest that aseismic processes operating in the deep crust or lithosphere such as those described above are mainly responsible for the ongoing vertical displacement rates in these regions, while the present-day trans-tensional seismicity is predominantly related to upper crustal processes accommodating the horizontal plate motion, i.e. the counterclockwise rotation of the Adria microplate (e.g. Anderson and Jackson, 1987; Collombet et al., 2002; Battaglia et al., 2004; Nocquet and Calais, 2004; D'Agostino et al., 2008; Rolland et al., 2012). Such processes may be conditioned by structural inheritance, e.g. the Penninic front and the Ivrea body (Sue et al., 2002). This interpretation implies uncoupled vertical and horizontal strain mechanisms and highlights a further intriguing aspect of the present-day Alpine tectonics in that aseismic vertical deformation is one order of magnitude higher than seismogenic horizontal strain.

\section{Conclusions}

Based on new and previously proposed models, we consider it unlikely that the isostatic response due to ice unloading during deglaciation is the only mechanism behind ongoing Alpine-scale vertical surface displacements. While such a proposal might, to some extent, apply to the Eastern Alps, this interpretation requires other mechanisms to counterbalance rock uplift rates due to ongoing crustal shortening/ thickening, the identification of which is not straightforward. We suggest that rock uplift rates due to the melting of the LGM Alpine ice-cap and erosion contribute up to $\sim 50 \%$ to the observed vertical displacement rates in the Western and Central Alps. This implies substantial contributions by convective processes (e.g., detachment of the western European slab) to the measured surface displacement rates, and we also support the view that the mechanisms of ongoing Alpine surface displacements include dynamic contributions related to the sub-lithospheric mantle flow.

In conclusion, although the European Alps are the most studied orogen worldwide, our knowledge regarding even the most recent and ongoing processes is still limited. This fact highlights the importance of collaborative research, because multidisciplinary datasets are required to improve the estimates and interpretations reported here, toward a better understanding of Alpine and, more generally, of orogenic dynamics.

Supplementary data to this article can be found online at https:// doi.org/10.1016/j.earscirev.2019.01.005.

\section{Declarations of interest}

None.

\section{Acknowledgements}

P.S. is grateful to the Swiss NSF for providing funding for this research (Ambizione grant PZ00P2_168113/1). P.G.V. acknowledges support from SNFS grant PP00P2_170559. G.S. is funded by a FFABR (Finanziamento delle Attività Base di Ricerca) grant of the Italian MIUR (Ministry of Education, University and Research). We are grateful to all public and private institutions and companies that make GPS data freely available for scientific applications. In particular, we acknowledge the EPN-EUREF network, the EPOSA and BEV networks in Austria, the ORPHEON (through RENAG), RGP and RENAG networks in France, the GREF network in Germany, the SIGNAL network in Slovenia, LeicaITALPOS, Topcon-NETGEO, ASI-GEODAF, INGV-RING, InOGSFREDNET networks in Italy, and all regional networks in Italy (FOGER Emilia-Romagna, Rete "Antonio Marussi" in Friuli Venezia Giulia, Regione Liguria, SPINGNSS in Piemonte and Lombardia, STPOS and TPOS in Trentino-Alto Adige and Regione Veneto). We thank Elmar Brockmann for providing velocities for the Swisstopo GNSS network in Swiss. We are grateful to Liang Zhao for sharing with us the tomography model. The manuscript has greatly improved following suggestions by Liviu Matenco and two anonymous reviewers.

\section{References}

Altamimi, Z., Collilieux, X., Métivier, L., 2011. ITRF2008: an improved solution of the international terrestrial reference frame. J. Geodesy. 85 (8), 457-473.

Anderson, H., Jackson, J., 1987. Active tectonics of the Adriatic region. Geophys. J. Int. 91 (3), 937-983.

Argand, E., 1916. Sur l'arc des Alpes Occidentales. Eclogae Helveticae 14, 145-191.

Avouac, J.P., Burov, E.B., 1996. Erosion as a driving mechanism of intracontinental mountain growth. J. Geophys. Res. 101, 17-747.

Baran, R., Friedrich, A.M., Schlunegger, F., 2014. The late Miocene to Holocene erosion pattern of the Alpine foreland basin reflects Eurasian slab unloading beneath the western Alps rather than global climate change. Lithosphere 6 (2), 124-131.

Barletta, V.R., Ferrari, C., Diolaiuti, G., Carnielli, T., Sabadini, R., Smiraglia, C., 2006. Glacier shrinkage and modeled uplift of the Alps. Geophys. Res. Lett. 33 (14).

Battaglia, M., Murray, M.H., Serpelloni, E., Burgman, R., 2004. The Adriatic region: An independent microplate within the Africa-Eurasia collision zone. Geophys. Res. Lett. 31 (9).

Bauve, V., Plateaux, R., Rolland, Y., Sanchez, G., Bethoux, N., Delouis, B., Darnault, R., 2014. Long-lasting transcurrent tectonics in SW Alps evidenced by Neogene to present-day stress fields. Tectonophysics $621,85-100$.

Becker, T., Faccenna, C., 2011. Mantle conveyor beneath the Tethyan collisional belt. Earth Planet. Sci. Lett. 310, 453-461.

Becker, T.W., Lowry, A.R., Faccenna, C., Schmandt, B., Borsa, A., Yu, C., 2015. Western U.S. intermountain seismicity caused by changes in upper mantle flow. Nature 524, 458-461.

Behm, M., Brückl, E., Chwatal, W., Thybo, H., 2007. Application of stacking and inversion techniques to three-dimensional wide-angle reflection and refraction seismic data of the Eastern Alps. Geophys. J. Int. 170 (1), 275-298.

Beller, S., Monteiller, V., Operto, S., Nolet, G., Paul, A., Zhao, L., 2017. Lithospheric architecture of the South-Western Alps revealed by multiparameter teleseismic fullwaveform inversion. Geophys. J. Int. 212 (2), 1369-1388.

Bennett, R.A., Hreinsdóttir, S., Buble, G., Bašić, T., Bačić, Z., Marjanović, M., Casale, G., Gendaszek, A., Cowan, D., 2008. Eocene to present subduction of southern Adria mantle lithosphere beneath the Dinarides. Geology 36 (1), 3-6.

Bistacchi, A., Massironi, M., 2000. Post-nappe brittle tectonics and kinematic evolution of the north-western Alps: an inte- grated approach. Tectonophysics 327, 267-292.

Boutoux, A., Bellahsen, N., Nanni, U., Pik, R., Verlaguet, A., Rolland, Y., Lacombe, O., 2016. Thermal and structural evolution of the external Western Alps: Insights from (U-Th-Sm)/He thermochronology and RSCM thermometry in the Aiguilles Rouges/ Mont Blanc massifs. Tectonophysics 683, 109-123.

Braun, J., 2010. The many surface expressions of mantle dynamics. Nature Geoscience 3, 825-833.

Brocard, G.Y., Van Der Beek, P.A., Bourlès, D.L., Siame, L.L., Mugnier, J.L., 2003. Longterm fluvial incision rates and postglacial river relaxation time in the French Western Alps from 10Be dating of alluvial terraces with assessment of inheritance, soil development and wind ablation effects. Earth Planet. Sci. Lett. 209 (1-2), 197-214.

Bruyninx, C., 2004. The EUREF permanent network: a multi-disciplinary network serving surveyors as well as scientists. GeoInformatics 7, 32-35.

Buechi, M., Kober, F., Ivy-Ochs, S., Salcher, B., Kubik, P.W., Christl, M., 2014. Denudation rates of small transient catchments controlled by former glaciation: The Hörnli nunatak in the northeastern Swiss Alpine Foreland. Quaternary Geochronol. 19, 135-147.

Campani, M., Mancktelow, N., Seward, D., Rolland, Y., Müller, W., Guerra, I., 2010. Geochronological evidence for continuous exhumation through the ductile-brittle transition along a crustal-scale low-angle normal fault: Simplon Fault Zone, central Alps. Tectonics 29 (3).

Carminati, E., Doglioni, C., 2012. Alps vs. Apennines: the paradigm of a tectonically asymmetric Earth. Earth Sci. Rev. 112 (1-2), 67-96.

Carminati, E., Martinelli, G., 2002. Subsidence rates in the Po Plain, northern Italy: the relative impact of natural and anthropogenic causation. Eng. Geol. 66 (3-4), 241-255.

Castelltort, S., Van Den Driessche, J., 2003. How plausible are high-frequency sediment supply-driven cycles in the stratigraphic record? Sediment. Geol. 157 (1), 3-13.

Cazenave, A., Souriau, A., Dominih, K., 1989. Global coupling of Earth surface topography with hotspots, geoid and mantle heterogeneities. Nature 340 (6228), 54. 
Champagnac, J.D., Sue, C., Delacou, B., Tricart, P., Allanic, C., Burkhard, M., 2006. Miocene lateral extrusion in the inner western Alps revealed by dynamic fault analysis. Tectonics. https://doi.org/10.1029/20 04TC001779.

Champagnac, J.D., Molnar, P., Anderson, R.S., Sue, C., Delacou, B., 2007. Quaternary erosion-induced isostatic rebound in the western Alps. Geology 35, 195-198.

Champagnac, J.D., Schlunegger, F., Norton, K., von Blanckenburg, F., Abbühl, L.M., Schwab, M., 2009. Erosion-driven uplift of the modern Central Alps. Tectonophysics 474 (1-2), 236-249.

Chery, J., Genti, M., Vernant, P., 2016. Ice cap melting and low-viscosity crustal root explain the narrow geodetic uplift of the Western Alps. Geophys. Res. Lett. 43 (7), 3193-3200.

Chittenden, H., Delunel, R., Schlunegger, F., Akçar, N., Kubik, P., 2013. The influence of bedrock orientation on the landscape evolution, surface morphology and denudation (10Be) at the Niesen, Switzerland. Earth Surf. Process. Landforms 39 (9), 1153-1166.

Christensen, U.R., 1998. Dynamic phase boundary topography by latent heat effects. Earth Planet. Sci. Lett. 154 (1-4), 295-306.

Cianetti, S., Giunchi, C., Spada, G., 2002. Mantle viscosity beneath the Hudson Bay: an inversion based on the Metropolis algorithm. J. Geophys. Res. 107 (B12).

Cloetingh, S., Bada, G., Matenco, L., Lankreijer, A., Horváth, F., Dinu, C., 2006. Modes of basin (de) formation, lithospheric strength and vertical motions in the PannonianCarpathian system: inferences from thermo-mechanical modelling. Geol. Soc. London, Memoirs 32 (1), 207-221.

Codilean, A.T., Munack, H., Cohen, T.J., Saktura, W.M., Gray, A., Mudd, S.M., 2018 OCTOPUS: An Open Cosmogenic Isotope and Luminescence Database. Earth Syst. Sci. Data Discuss. https://doi.org/10.5194/essd-2018-32. in review.

Collombet, M., Thomas, J.C., Chauvin, A., Tricart, P., Bouillin, J.P., Gratier, J.P., 2002 Counterclockwise rotation of the western Alps since the Oligocene: New insights from paleomagnetic data. Tectonics 21 (4).

D'Agostino, N., Avallone, A., Cheloni, D., D'anastasio, E., Mantenuto, S., Selvaggi, G. 2008. Active tectonics of the Adriatic region from GPS and earthquake slip vectors. J. Geophys. Res. 113 (B12).

Delacou, B., Sue, C., Champagnac, J.D., Burkhard, M., 2004. Present-day geodynamics in the bend of the western and central Alps as constrained by earthquake analysis. Geophys. J. Int. 158 (2), 753-774.

Delacou, B., Sue, C., Champagnac, J.D., Burkhard, M., 2005. Origin of the current stress field in the Western/Central Alps: role of gravitational reequilibration constrained by numerical modelling. Geol. Soc. London Spec. Publ. 243, 295-310.

Delunel, R., Van Der Beek, P.A., Carcaillet, J.B., Bourlès, D.L., Valla, P.G., 2010. Frostcracking control on catchment denudation rates: Insights from in situ produced 10Be concentrations in stream sediments (Ecrins-Pelvoux massif, French Western Alps). Earth Planet. Sci. Lett. 293 (1-2), 72-83.

van den Berg, F., Schlunegger, F., Akçar, N., Kubik, P., 2012. 10Be-derived assessment of accelerated erosion in a glacially conditioned inner gorge, Entlebuch, Central Alps of Switzerland. Earth Surf. Process. Landforms 37 (11), 1176-1188.

van der Beek, P., Bourbon, P., 2008. A quantification of the glacial imprint on relief development in the French western Alps. Geomorphology 97 (1-2), 52-72.

Di Stefano, R., Kissling, E., Chiarabba, C., Amato, A., Giardini, D., 2009. Shallow subduction beneath Italy: Three-dimensional images of the Adriatic-EuropeanTyrrhenian lithosphere system based on high-quality P wave arrival times. J. Geophys. Res. 114 (B5).

Digby, P.J., 1981. The effective elastic moduli of porous granular rocks. J. Appl. Mech. 48 (4), 803-808.

Dixon, J.L., von Blanckenburg, F., Stuwe, K., Christl, M., 2016. Glaciation's topographic control on Holocene erosion at the eastern edge of the Alps. Earth Surface Dyn. https://doi.org/10.5194/esurf-4-895-2016.

Doglioni, C., 1990. "Thrust tectonics examples from the Venetian Alps." Atti del Convegno: Neogene thrust tectonics. Studi Geol. Camerti 117-129 Vol. Spec.

Doglioni, C., 1992. The Venetian Alps thrust belt. In: Thrust Tectonics. Springer, Dordrecht, pp. 319-324.

Dong, D., Herring, T., King, R., 1998. Estimating regional deformation from a combination of space and terrestrial geodetic data. J. Geodesy 72 (4), 200-214. https://doi. org $/ 10.1007 /$ s001900050161.

Duretz, T., Gerya, T.V., 2013. Slab detachment during continental collision: Influence of crustal rheology and interaction with lithospheric delamination. Tectonophysics 602, $124-140$.

Duretz, T., Gerya, T., Spakman, W., 2014. Slab detachment in laterally varying subduction zones: 3D numerical modeling. Geophys. Res. Lett. https://doi.org/10.1002/ 2014GL059472.

Ehlers, J., Gibbard, P.L., 2004. Quaternary glaciations-extent and chronology: part I: Europe. Elsevier.

England, P., Molnar, P., 1990. Surface uplift, uplift of rocks, and exhumation of rocks. Geology 18, 1173-1177.

Eva, E., Solarino, S., 1998. Variations of stress directions in the Western Alpine arc. Geophys. J. Int. 135, 438-448.

Faccenna, C., Becker, T., Miller, M.S., Serpelloni, E., Willett, S.D., 2014. Isostasy, dynamic topography, and the elevation of the Apennines of Italy. Earth and Planetary Science Letters 407, 163-174.

Falus, G., Szabó, C., Vaselli, O., 2000. Mantle upwelling within the Pannonian Basin: evidence from xenolith lithology and mineral chemistry. Terra Nova 12 (6), 295-302.

Farrell, W.E., Clark, J.A., 1976. On postglacial sea level. Geophys. J. R. Astr. Soc. 46 647-667.

Flament, N., Gurnis, M., Müller, R.D., 2013. A review of observations and models of dynamic topography. Lithosphere 5 (2), 189-210.

Forte, A.M., Mitrovica, J.X., 1996. New inferences of mantle viscosity from joint inversion of long-wavelength mantle convection and post-glacial rebound data. Geophys. Res. Lett. 23 (10), 1147-1150.
Fox, M., Herman, F., Kissling, E., Willett, S.D., 2015. Rapid exhumation in the Western Alps driven by slab detachment and glacial erosion. Geology 43 (5), 379-382.

Glotzbach, C., Van Der Beek, P.A., Spiegel, C., 2011. Episodic exhumation and relief growth in the Mont Blanc massif, Western Alps from numerical modelling of thermochronology data. Earth Planet. Sci. Lett. 304 (3-4), 417-430.

Glotzbach, C., van der Beek, P., Carcaillet, J., Delunel, R., 2013. Deciphering the driving forces of erosion rates on millennial to million-year timescales in glacially impacted landscapes: An example from the Western Alps. J. Geophys. Res. 118 (3), 1491-1515.

Grischott, R., Kober, F., Lupker, M., Hippe, K., Ivy-Ochs, S., Hajdas, I., Salcher, B., Christl, M., 2016. Constant denudation rates in a high alpine catchment for the last 6 kyrs. Earth Surf. Process. Landforms 42 (7), 1065-1077.

Grischott, R., Kober, F., Lupker, M., Reitner, J.M., Drescher-Schneider, R., Hajdas, I., Christl, M., Willett, S.D., 2017. Millennial scale variability of denudation rates for the last 15 kyr inferred from the detrital 10Be record of Lake Stappitz in the Hohe Tauern massif, Austrian Alps. Holocene 27 (12), 1914-1927.

Gubler, E., Kahle, H.G., Klingele, E., Olivier, R., 1981. Recent crustal movements in Switzerland and their geophysical interpretation. In: Developments in Geotectonics. 16. pp. 125-152.

Gudmundsson, G.H., 1994. An order-of-magnitude estimate of the current uplift-rates in Switzerland caused by the Würm Alpine deglaciation. Eclogae Geologicae Helvetiae 87 (2), 545-557.

Gurnis, M., 1993. Phanerozoic marine inundation of continents driven by dynamic to pography above subducting slabs. Nature 364 (6438), 589.

Gvirtzman, Z., Faccenna, C., Becker, T.W., 2016. Isostasy, flexure, and dynamic topography. Tectonophys 683, 255-271.

Hager, B.H., Clayton, R.W., Richards, M.A., Comer, R.P., Dzievonski, A.M., 1985. Lower mantle heterogeneity, dynamic topography and the geoid. Nature 313 (6003), 541.

Handy, M.R., Ustaszewski, K., Kissling, E., 2015. Reconstructing the Alps-Carpathians-Dinarides as a key to understanding switches in subduction polarity, slab gaps and surface motion. Int. J. Earth Sci. 104 (1), 1-26.

Häuselmann, P., Fiebig, M., Kubik, P.W., Adrian, H., 2007. A first attempt to date the original "Deckenshotter" of Penck and Brückner with cosmogenic nuclides. Quat. Int. 164-165, 33-42.

Heiskanen, W.A., Vening Meinesz, F.A., 1958. The Earth and Its Gravity Field. Inc. McGrav Hill Book Company, New York.

Herman, F., Beaud, F., Champagnac, J.D., Lemieux, J.M., Sternai, P., 2011. Glacial hydrology and erosion patterns: A mechanism for carving glacial valleys. Earth Planet. Sci. Lett. 310, 498-508.

Herman, F., Seward, D., Valla, P.G., Carter, A., Kohn, B., Willett, S.D., Ehlers, T.A., 2013. Worldwide acceleration of mountain erosion under a cooling climate. Nature 504

Herring, T.A., King, R.A., Floyd, M.A., McClusky, S.C., 2015. Introduction to GAMIT/ GLOBK, Release 10.6. Retrieved from. http://www-gpsg.mit.edu/ simon/gtgk/ Intro_GG.pdf.

Hinderer, M., 2001. Late Quaternary denudation of the Alps, valley and lake fillings and modern river loads. Geodinamica Acta 14 (4), 231-263.

Hinderer, M., Kastowski, M., Kamelger, A., Bartolini, C., Schlunegger, F., 2013. River loads and modern denudation of the Alps-a review. Earth Sci. Rev. 118, 11-44.

Husson, L., Bernet, M., Guillot, S., Huyghe, P., Mugnier, J.L., Replumaz, A., Robert, X., Van der Beek, P., 2014. Dynamic ups and downs of the Himalaya. Geology 42 (10), 839-842.

Husson, L., Bodin, T., Spada, G., Choblet, G., Kreemer, C., 2018. Bayesian surface reconstruction of geodetic uplift rates: Mapping the global fingerprint of Glacial Isostatic Adjustment. J. Geodyn. 122, 25-40.

Ivy-Ochs, S., Kerschner, H., Reuther, A., Maisch, M., Sailer, R., Schaefer, J., Kubik, P.W., Synal, H., Schluchter, C., 2006. IThe timing of glacier advances in the northern European Alps based on surface exposure dating with cosmogenic^ $1^{\wedge} 0 \mathrm{Be}, 2^{\wedge}$ “ $6 \mathrm{Al}$, , 3 ^ $6 \mathrm{Cl}$, and^ $2^{\wedge} 1 \mathrm{Ne}$. In: Special Papers. 415. Geological Society of America, pp. 43.

Jackson, I., Paterson, M.S., 1987. Shear modulus and internal friction of calcite rocks at seismic frequencies: Pressure, frequency and grain size dependence. Phys. Earth Planet. Interiors 45 (4), 349-367.

Jouanne, F., Ménard, G., Darmendrail, X., 1995. Present-day vertical displacements in the north-western Alps and southern Jura Mountains: Data from leveling comparisons. Tectonics 14 (3), 606-616.

Kästle, E.D., El-Sharkawy, A., Boschi, L., Meier, T., Rosenberg, C., Bellahsen, N., N., et al., 2018. Surface wave tomography of the Alps using ambient-noise and earthquake phase velocity measurements. J. Geophys. Res. 123, 1770-1792.

Kissling, E., 1993. Deep structure of the Alps-what do we really know? Phys. Earth Planet. Interiors 79 (1-2), 87-112.

Kissling, E., Schmid, S.M., Lippitsch, R., Ansorge, J., Fügenschuh, B., 2006. Lithosphere structure and tectonic evolution of the Alpine arc: new evidence from high-resolution teleseismic tomography. Geol. Soc., London, Memoirs 32 (1), 129-145.

Koppes, M.N., Montgomery, D.R., 2009. The relative efficacy of fluvial and glacial erosion over modern to orogenic timescales. Nat. Geosci. 2, 644-647.

Korup, O., Schlunegger, F., 2007. Bedrock landsliding, river incision, and transience of geomorphic hillslope-channel coupling: Evidence from inner gorges in the Swiss Alps. J. Geophys. Res. 112 (F3).

Koulakov, I., Kaban, M.K., Tesauro, M., Cloetingh, S.A., 2009. P- and S-velocity anomalies in the upper mantle beneath Europe from tomographic inversion of ISC data. Geophys. J. Int. 179, 345-366.

Kuhlemann, J., Frisch, W., Székely, B., Dunkl, I., Kazamér, M., 2002. Post-collisional sediment budget history of the Alps: tectonic versus climatic control. Int. J. Earth Sci. 91, 818-837.

Lachenbruch, A.H., Morgan, P., 1990. Continental extension, magmatism and elevation; formal relations and rules of thumb. Tectonophysics 174, 39-62.

Laske, G., Masters, G., Ma, Z., Pasyanos, M., 2013. Update on CRUST1.0 - A 1-degree Global Model of Earth's Crust. Geophys. Res. Abstracts 15 Abstract EGU2013-2658. 
http://igppweb.ucsd.edu/ gabi/crust1.html.

Le Stunff, Y., Ricard, Y., 1995. Topography and geoid due to lithospheric mass anomalies. Geophys. J. Int. 122 (3), 982-990.

Li, C., van der Hilst, R., Engdahl, E.R., Burdick, S., 2008. A new global model for P wave speed variations in Earth's mantle. Geochem. Geophys. Geosyst. 9 (5).

Lippitsch, R., Kissling, E., Ansorge, J., 2003. Upper mantle structure beneath the Alpine orogen from high-resolution teleseismic tomography. J. Geophys. Res. 108, 108. https://doi.org/10.1029/2002JB002016.

Lithgow-Bertelloni, C., Silver, P.G., 1998. Dynamic topography, plate driving forces and the African superswell. Nature 395 (6699), 269.

Mancin, N., Di Giulio, A., Cobianchi, M., 2009. Tectonic vs. climate forcing in the Cenozoic sedimentary evolution of a foreland basin (Eastern Southalpine system, Italy). Basin Res. 21 (6), 799-823.

Maurer, H., Burkhard, M., Diechmann, N., Green, A.G., 1997. Active tectonism in the Central Alps: contrasting stress regimes north and south of the Rhone Valley. Terra Nova 9, 91-94.

Mey, J., Scherler, D., Wickert, A.D., Egholm, D.L., Tesauro, M., Schildgen, T., Strecker, M.R., 2016. Glacial isostatic uplift of the European Alps. Nature Commun. https:// doi.org/10.1038/ncomms13382.

Mitterbauer, U., Behm, M., Brückl, E., Lippitsch, R., Guterch, A., Keller, G.R., Koslovskaya, E., Rumpfhuber, E.M., Šumanovac, F., 2011. Shape and origin of the East-Alpine slab constrained by the ALPASS teleseismic model. Tectonophysics 510 (1-2), 195-206.

Molinari, I., Morelli, A., 2011. EPcrust: a reference crustal model for the European Plate. Geophys. J. Int. 185 (1), 352-364.

Molliex, S., Rabineau, M., Leroux, E., Bourlès, D.L., Authemayou, C., Aslanian, D., et al., 2016. Multi-approach quantification of denudation rates in the Gulf of Lion source-tosink system (SE France). Earth Planet. Sci. Lett. 444, 101-115.

Molnar, P., England, P., 1990. Late Cenozoic uplift of mountain ranges and global climate change: chicken or egg? Nature 346 (6279), 29-34.

Muttoni, G., Carcano, C., Garzanti, E., Ghielmi, M., Piccin, A., Pini, R., Rogledi, S., Sciunnach, D., 2003. Onset of major Pleistocene glaciations in the Alps. Geology 31 (11), 989-992.

Nocquet, J.M., Calais, E., 2004. Geodetic measurements of crustal deformation in the Western Mediterranean and Europe. Pure Appl. Geophys. 161 (3), 661-681.

Nocquet, J.M., Sue, C., Walsperdorf, A., Tran, T., Lenotre, N., Vernant, P., Cushing, M., Jouanne, F., Masson, F., Baize, S., Chery, J., 2016. Present-day uplift of the western Alps. Sci. Rep. 6, 28404.

Norton, K.P., Hampel, A., 2010. Postglacial rebound promotes glacial re-advances - a case study from the European Alps. Terra Nova 22 (4), 297-302.

Norton, K.P., von Blanckenburg, F., Schlunegger, F., Schwab, M., Kubik, P., 2008. Cosmogenic nuclide-based investigation of spatial erosion and hillslope channel coupling in the transient foreland of the Swiss Alps. Geomorphology 95 (3-4), 474-486.

Norton, K.P., von Blanckenburg, F., Kubik, P.W., 2010. Cosmogenic nuclide-derived rates of diffusive and episodic erosion in the glacially sculpted upper Rhone Valley, Swiss Alps. Earth Surf. Process. Landf. 35 (6), 651-662.

Norton, K.P., von Blanckenburg, F., DiBiase, R., Schlunegger, F., Kubik, P., 2011. Cosmogenic 10 Be-derived denudation rates of the Eastern and Southern European Alps. Int. J. Earth Sci. 100 (5), 1163-1179.

Panasyuk, S.V., Hager, B.H., 2000. Models of isostatic and dynamic topography, geoid anomalies, and their uncertaintie. J. Geophys. Res. 105 (B12), 28199-28,209.

Peizhen, Z., Molnar, P., Downs, W.R., 2001. Increased sedimentation rates and grain sizes 2-4 Myr ago due to the influence of climate change on erosion rates. Nature 410, 891-897.

Peltier, W., 2004. Global glacial isostasy and the surface of the ice-age earth: the ICE5G(VM2) model and GRACE. Annu. Rev. Earth Planet. Sci. 32, 111-149.

Penck, A., 1905. Glacial features in the surface of the Alps. J. Geol. 13, 1-19.

Petit, C., Goren, L., Rolland, Y., Bourlès, D., Braucher, R., Saillard, M., Cassol, D., 2017 Recent, climate-driven river incision rate fluctuations in the Mercantour crystalline massif, southern French Alps. Quat. Sci. Rev. 165, 73-87.

Piromallo, C., Faccenna, C., 2004. How deep can we find the traces of Alpine subduction? Geophys. Res. Lett. 31 (6)

Piromallo, C., Morelli, A., 1997. Imaging the Mediterranean upper mantle by P-wave travel time tomography. Ann. Geofis. XL (4).

Preusser, F., Reitner, J.M., Schluchter, C., 2010. Distribution, geometry, age and origin of overdeepened valleys and basins in the Alps and their foreland. Swiss J. Geosci. 103, 407-426.

Ratschbacher, L., Frisch, W., Linzer, H.G., Merle, O., 1991. Lateral extrusion in the Eastern Alps, part 2: structural analysis. Tectonics 10 (2), 257-271.

Raymo, M.E., Ruddiman, W.F., 1992. Tectonic forcing of late Cenozoic climate. Nature 359 (6391), 117-122.

Rebischung, P., Griffiths, J., Ray, J., Schmid, R., Collilieux, X., Garayt, B., 2012. IGS08: the IGS realization of ITRF2008. GPS Solutions 16 (4), 483-494.

Rolland, Y., Lardeaux, J.M., Jolivet, L., 2012. Deciphering orogenic evolution. J. Geodyn. $56,1-6$.

Rolland, T., Petit, C., Saillard, M., Braucher, R., Bourlès, D., Darnault, R., Cassol, D., ASTER team, 2017. Inner gorges incision history: A proxy for deglaciation? Insights from Cosmic Ray Exposure dating (10Be and 36Cl) of river-polished surfaces (Tinée River, SW Alps, France). Earth Planet. Sci. Lett. 457, 271-281.

Romans, B.W., Castelltort, S., Castelltort, S., Covault, J.A., Fildani, A., Walsh, J.P., 2016. Environmental signal propagation in sedimentary systems across timescales. EarthSci. Rev. 153, 7-29.

Rosenbaum, G., Lister, G.S., 2004. Neogene and quaternary rollback evolution of the tyrrhenian sea, the apennines, and the sicilian maghrebides. Tectonics 23 (1).

Royden, L., Horváth, F., Nagymarosy, A., Stegena, L., 1983. Evolution of the Pannonian basin system: 2. Subsidence and thermal history. Tectonics 2 (1), 91-137.

Ruddiman, W.F., 1997. Tectonic Uplift and Climate Change. Springer.

Saillard, M., Petit, C., Rolland, Y., Braucher, R., Bourlès, D.L., Zerathe, S., Revel, M., Jourdon, A., 2014. Late Quaternary incision rates in the Vésubie catchment area (Southern French Alps) from in situ-produced $36 \mathrm{Cl}$ cosmogenic nuclide dating: Tectonic and climatic implications. J. Geophys. Res. 119 (5), 1121-1135.

Sanchez, G., Rolland, Y., Jolivet, M., Brichau, S., Corsini, M., Carter, A., 2011. Exhumation controlled by transcurrent tectonics: the Argentera-Mercantour massif (SW Alps). Terra Nova 23, 116-126.

Savi, S., Norton, K.P., Picotti, V., Brardinoni, F., Akçar, N., Kubik, P., et al., 2014. Effects of sediment mixing on 10Be concentrations in the Zielbach catchment, centraleastern Italian Alps. Quat. Geochronol. 19, 148-162.

Schaer, J.P., Jeanrichard, F., 1974. Mouvements verticaux anciens et actuels dans les Alpes suisses. Eclogae Geol. Helv. 67 (1), 101-119.

Schlatter, A., Schneider, D., Geiger, A., Kahle, H.G., 2005. Recent vertical movements from precise levelling in the vicinity of the city of Basel, Switzerland. Int. J. Earth Sci. 94 (4), 507-514.

Schlunegger, F., Hinderer, M., 2001. Crustal uplift in the Alps: why the drainage pattern matters. Terra Nova 13 (6), 425-432.

Schmid, S.M., Fugenshuh, B., Kissling, E., Schuster, R., 2004. Tectonic map and overall architecture of the Alpine orogen. Eclogae Geol. Helv. 93-117. https://doi.org/10. 1007/s00015-004-1113-x.

Schmid, S.T., Kissling, E., Diehl, T., van Hinsber, D., Molli, G., 2017. Ivrea mantle wedge, arc of the Western Alps, and kinematic evolution of the Alps-Apennines orogenic system. Swiss J. Geosci. 110 (2), 581-612.

Schreiber, D., Lardeaux, J.M., Martelet, G., Courrioux, G., Guillen, A., 2010. 3-D modelling of Alpine mohos in southwestern Alps. Geophys. J. Int. 180 (3), 961-975.

Schwartz, S., Gautheron, C., Audin, L., Dumont, T., Nomade, J., Barbarand, J., ... van der Beek, P., 2017. Foreland exhumation controlled by crustal thickening in the Western Alps. Geology 45 (2), 139-142.

Serpelloni, E., Faccenna, C., Spada, G., Dong, D., Williams, S.D., 2013. Vertical GPS ground motion rates in the Euro-Mediterranean region: New evidence of velocity gradients at different spatial scales along the Nubia-Eurasia plate boundary. J. Geophys. Res. 118, 6003-6024.

Serpelloni, E., Vannucci, G., Anderlini, L., Bennett, R.A., 2016. Serpelloni, E., Vannucci, G., Anderlini, L. and Bennett, R.A., 2016. Kinematics, seismotectonics and seismic potential of the eastern sector of the European Alps from GPS and seismic deformation data. Tectonophysics $688,157-181$.

Serpelloni, E., Pintori, F., Gualandi, A., Scoccimarro, E., Cavaliere, A., Anderlini, L., et al., 2018. Hydrologically induced karst deformation: Insights from GPS measurements in the Adria-Eurasia plate boundary zone. J. Geophys. Res. 123, 4413-4430.

Simmons, N.A., Forte, A., Boschi, L., Grand, S.P., 2010. GyPSuM: a joint tomographic model of mantle density and seismic wave speeds. J. Geophys. Res. 115 (B12).

Slejko, D., Carulli, G.B., Nicolich, R., Rebez, A., Zanferrari, A., Cavallin, A., Doglioni, C. Carraro, F., Castaldini, D., Iliceto, V., Semenza, E., 1989. Seismotectonics of the Eastern Southern Alps: a review. Boll. Geofis. Teor. Appl. 31, 109-136.

Small, E.E., Anderson, R.S., 1998. Pleistocene relief production in Laramide mountain ranges, western United States. Geology 26 (2), 123-126.

Spada, G., Stocchi, P., Colleoni, F., 2009. Glacio-isostatic adjustment in the po plain and in the northern adriatic region. Pure Appl. Geophys. 1303-1318. https://doi.org/10. 1007/s00024-004-0498-9.

Spada, M., Bianchi, I., Kissling, E., Agostinetti, N.P., Wiemer, S., 2013. Combining controlled-source seismology and receiver function information to derive 3-D Moho topography for Italy. Geophys. J. Int. 194 (2), 1050-1068.

Spakman, W., Wortel, R., 2004. A tomographic view on western Mediterranean geodynamics. In: The TRANSMED Atlas. The Mediterranean Region From Crust to Mantle. Springer, Berlin, Heidelberg, pp. 31-52.

Steinberger, B., Calderwood, A.R., 2006. Models of large-scale viscous flow in the Earth's mantle with constraints from mineral physics and surface observations. Geophys. J. Int. 167 (3), 1461-1481.

Sternai, P., Herman, F., Fox, M.R., Castelltort, S., 2011. Hypsometric analysis to identify spatially variable glacial erosion. J. Geophys. Res. 116 (F03001). https://doi.org/10. 1029/2010JF001823.

Sternai, P., Herman, F., Champagnac, J.-D., Fox, M., Salcher, B., Willett, S.D., 2012. Preglacial topography of the European Alps. Geology 40 (12), 1067-1070.

Sternai, P., Herman, F., Valla, P.G., Champagnac, J.-D., 2013. Spatial and temporal variations of glacial erosion in the Rhône valley (Swiss Alps): Insights from numerical modeling. Earth Planet. Sci. Lett. 368, 119-131.

Sternai, P., Avouac, J.-P., Jolivet, L., Faccenna, C., Gerya, T.V., Becker, T.W., Menant, A., 2016a. On the influence of the asthenospheric flow on the tectonics and topography at a collision-subduction transition zones: Comparison with the eastern Tibetan margin. J. Geodyn. 100, 184-197.

Sternai, P., Caricchi, L., Castelltort, S., Champagnac, J.-D., 2016b. Deglaciation and glacial erosion: a joint control on magma productivity by continental unloading Geophys. Res. Lett. 43 (4), 1632-1641.

Stocchi, P., Spada, G., Cianetti, S., 2005. Isostatic rebound following the Alpine deglaciation: impact on the sea level variations and vertical movements in the Mediterranean region. Geophys. J. Int. 162 (1), 137-147.

Stucki, M.D., Schlunegger, F., 2013. Identification of erosional mechanisms during past glaciations based on a bedrock surface model of the central European Alps. Earth Planet. Sci. Lett. 384, 57-70.

Sue, C., Tricart, P., 2003. Neogene to ongoing normal faulting in the inner western Alps: a major evolution of the alpine tectonics. Tectonics 22, 1-25.

Sue, C., Thouvenot, F., Fréchet, J., Tricart, P., 1999. Widespread extension in the core of the western Alps revealed by earthquake analysis. J. Geophys. Res. 104 (B11), 25611-25622. 
Sue, C., Grasso, J.R., Lahaie, F., Amitrano, D., 2002. Mechanical behavior of western alpine structures inferred from statistical analysis of seismicity. Geophys. Res. Lett. 29, 65-69.

Sue, C., Delacou, B., Champagnac, J.D., Allanic, C., Tricart, P., Burkhard, M., 2007. Extensional neotectonics around the bend of the Western/Central Alps: an overview. Int. J. Earth Sci. 96, 1101-1129.

Sue, C., Delacou, B., Champagnac, J.D., Allanic, C., Burkhard, M., 2007b. Aseismic deformation in the Alps: GPS vs. seismic strain quantification. Terra Nova 19 (3), 182-188.

Šumanovac, F., 2015. Lithosphere model of the Pannonian-Adriatic overthrusting. Tectonophysics 665, 79-91.

Tesauro, M., Kaban, M.K., Cloetingh, S.A., 2008. EuCRUST-07: A new reference model for the European crust. Geophys. Res. Lett. 35 (L05313).

Tesauro, M., Kaban, M.K., Cloetingh, S.A., 2013. Global model for the lithospheric strength and effective elastic thickness. Tectonophysics 602, 78-86.

Tricart, P., Lardeaux, J.M., Schwartz, S., Sue, C., 2006. The late extension in the inner western Alps: a synthesis along the south-Pelvoux transect. Bull. Soc. Geol. Fr. 177, 299-310.

Turcotte, D.L., Schubert, G., 2002. Geodynamics. Cambridge University Press, Cambridge.

Valla, P., van der Beek, P.A., Lague, D., 2010. Fluvial incision into bedrock: insights from morphometric analysis and numerical modeling of gorges incising glacial hanging valleys (Western Alps, France). J. Geophys. Res. 115.

Valla, P.G., Shuster, D.L., van der Beek, P.A., 2011. Significant increase in relief of the European Alps during mid-Pleistocene glaciations. Nat. Geosci. 4, 688-692.

Vernant, P., Hivert, F., Chery, J., Steer, P., Cattin, R., Rigo, A., 2013. Erosion-induced isostatic rebound triggers extension in low convergent mountain ranges. Geology 41, 467-470.

Vignaroli, G., Faccenna, C., Jolivet, L., Piromallo, C., Rossetti, F., 2008. Subduction polarity reversal at the junction between the Western Alps and the Northern Apennines, Italy. Tectonophysics 450 (1-4), 34-50.

Vigny, C., Chery, J., Duquesnoy, T., Jouanne, F., Ammann, J., Anzidei, M., Avouac, J.P., Barlier, F., Bayer, R., Briole, P., et al., 2002. GPS network monitors the Western Alps' deformation over a five-year period: 1993-1998. J. Geodesy. 76, 63-76.
Wagner, M., Kissling, E., Husen, S., 2012. Combining controlled-source seismology and local earthquake tomography to derive a 3-D crustal model of the western Alpine region. Geophys. J. Int. 191 (2), 789-802.

Waldhauser, F., Lippitsch, R., Kissling, E., Ansorge, J., 2002. High-resolution teleseismic tomography of upper-mantle structure using an a priori three-dimensional crustal model. Geophys. J. Int. 150 (2), 403-414.

Walpersdorf, A., Sue, C., Baize, S., Cotte, N., Bascou, P., Beauval, C., Collard, P., Daniel, G., Dyer, H., Grasso, J.R., Hautecoeur, O., 2015. Coherence between geodetic and seismic deformation in a context of slow tectonic activity (SW Alps, France). J. Geodyn. 85, 58-65.

Watts, A.B., 2009. Isostasy and flexure of the lithosphere. Cambridge University Press, Cambridge.

Willenbring, J.K., Jerolmack, D.J., 2016. The null hypothesis: globally steady rates of erosion, weathering fluxes and shelf sediment accumulation during Late Cenozoic mountain uplift and glaciation. Terra Nova 28 (1), 11-18.

Willett, S.D., 1999. Orogeny and orography: The effects of erosion on the structure of mountain belts. J. Geophys. Res. 104 (b12), 957-981.

Willett, S.D., 2010. Late Neogene erosion of the Alps: A climate driver? Annu. Rev. Earth Planet. Sci. 38, 411-437.

Wittmann, H., von Blanckenburg, F., Kruesmann, T., Norton, K., Kubik, P., 2007. Relation between rock uplift and denudation from cosmogenic nuclides in river sediment in the Central Alps of Switzerland. J. Geophys. Res. 112 (F4).

Wittmann, H., Malusà, M., Resentini, A., Garzanti, E., Niedermann, S., 2016. The cosmogenic record of mountain erosion transmitted across a foreland basin: Source-tosink analysis of in situ $10 \mathrm{Be}, 26 \mathrm{Al}$ and $21 \mathrm{Ne}$ in sediment of the Po river catchment. Earth Planet. Sci. Lett. 452, 258-271.

Wölfler, A., Dekant, C., Danišík, M., Kurz, W., Dunkl, I., Putiš, M., Frisch, W., 2008. Late stage differential exhumation of crustal blocks in the central Eastern Alps: evidence from fission track and (U-Th)/He thermochronology. Terra Nova 20 (5), 378-384.

Zhao, L., Paul, A., Malusà, M.G., Xu, X., Zheng, T., Solarino, S., Guillot, S., Schwartz, S. Dumont, T., Salimbeni, S., Aubert, C., 2016. Continuity of the Alpine slab unraveled by high-resolution P wave tomography. J. Geophys. Res. 121 (12), 8720-8737. 